\title{
Revisiting the loess/palaeosol sequence in Paks, Hungary: A post-IR IRSL based chronology for the 'Young Loess Series'
}

Thiel, Christine; Horváth, Erzsébet ; Frechen, Manfred

Published in:

Quaternary International

Link to article, DOI:

10.1016/j.quaint.2013.05.045

Publication date:

2014

Link back to DTU Orbit

Citation (APA):

Thiel, C., Horváth, E., \& Frechen, M. (2014). Revisiting the loess/palaeosol sequence in Paks, Hungary: A postIR IRSL based chronology for the 'Young Loess Series'. Quaternary International, 319, 88-98.

https://doi.org/10.1016/j.quaint.2013.05.045

\section{General rights}

Copyright and moral rights for the publications made accessible in the public portal are retained by the authors and/or other copyright owners and it is a condition of accessing publications that users recognise and abide by the legal requirements associated with these rights.

- Users may download and print one copy of any publication from the public portal for the purpose of private study or research.

- You may not further distribute the material or use it for any profit-making activity or commercial gain

- You may freely distribute the URL identifying the publication in the public portal

If you believe that this document breaches copyright please contact us providing details, and we will remove access to the work immediately and investigate your claim 


\section{Accepted Manuscript}

Revisiting the loess/palaeosol sequence in Paks, Hungary: A post-IR IRSL based chronology for the 'Young Loess Series'

Christine Thiel, Erzsébet Horváth, Manfred Frechen

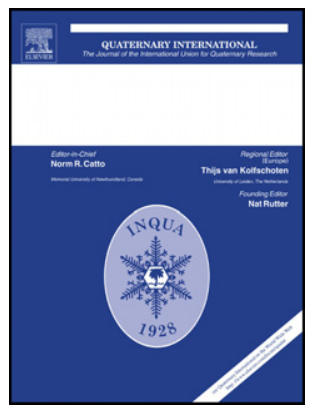

PII: S1040-6182(13)00310-8

DOI: $\quad$ 10.1016/j.quaint.2013.05.045

Reference: JQI 3812

To appear in: Quaternary International

Please cite this article as: Thiel, C., Horváth, E., Frechen, M., Revisiting the loess/palaeosol sequence in Paks, Hungary: A post-IR IRSL based chronology for the 'Young Loess Series', Quaternary International (2013), doi: 10.1016/j.quaint.2013.05.045.

This is a PDF file of an unedited manuscript that has been accepted for publication. As a service to our customers we are providing this early version of the manuscript. The manuscript will undergo copyediting, typesetting, and review of the resulting proof before it is published in its final form. Please note that during the production process errors may be discovered which could affect the content, and all legal disclaimers that apply to the journal pertain. 


\title{
Revisiting the loess/palaeosol sequence in Paks, Hungary: A post-IR IRSL based chronology for the 'Young Loess Series'
}

\author{
Christine Thiel ${ }^{1,2, *}$, Erzsébet Horváth ${ }^{3}$, Manfred Frechen ${ }^{4}$
}

${ }^{1}$ Nordic Laboratory for Luminescence Dating, Department of Geoscience, Aarhus University, DTU Ris $\varnothing$ Campus, Frederiksborgvej 399, 4000 Roskilde, Denmark

2 Center for Nuclear Technologies, Technical University of Denmark, Ris $\varnothing$ Campus, Frederiksborgvej 399, 4000 Roskilde, Denmark

${ }^{3}$ Department of Physical Geography, Eötvös Loránd University, Pázmány Péter sétány 1/c, 1117 Budapest, Hungary

${ }^{4}$ Leibniz Institute for Applied Geophysics (LIAG), Geochronology and Isotope Hydrology, Stilleweg 2, 30655 Hannover, Germany

* corresponding author: chrth@dtu.dk

\section{Abstract}

In Hungary, many loess/palaeosol sequences have been found to be discontinuous. In order to allow for correlations with other Quaternary records, reliable chronologies are needed. We therefore apply post-IR infrared (IR) stimulated luminescence (post-IR IRSL; pIRIR 290 ) dating to the uppermost $20 \mathrm{~m}$ of the loess sequence at Paks. The pIRIR 290 ages are compared with blue quartz OSL ages to test for potential age overestimation due to poor signal re-setting, and the observed good agreement is taken to imply that the more difficult to bleach pIRIR 290 signal was reset prior to deposition. Our pIRIR 290 based chronology reveals that most of the Late Pleistocene loess was deposited during marine isotope stage (MIS) 3 and during the Last Glacial Maximum (LGM). This is in disagreement with formerly published ages. The discrepancy can most likely be explained by anomalous fading (resulting in an age underestimate); this conclusion is supported by our uncorrected 'standard' IRSL ages. We further confirm that the Basaharc Double soil complex can be correlated with MIS 7; the underlying loess and soils cannot be dated accurately because the pIRIR $_{290}$ signal approaches saturation.

Keywords: Late Pleistocene; Middle Pleistocene; loess; OSL; post-IR IRSL; Hungary 


\section{Introduction}

The importance of loess/palaeosol sequences to the reconstruction of the landscape evolution and the palaeoenviroment in the Carpathian Basin has been pointed out by several studies (e.g. Bronger, 1975, 2003; Pécsi and Richter, 1996). In regions thought to be dominated by continuous loess deposits such as the Chinese loess plateau (e.g. Kukla, 1987) and the southeast Carpathian Basin (Vojvodina region; e.g. Marković et al., 2008, 2011; Fitzsimmons et al., 2012) interglacial soils can, within certain limits, be identified and regionally correlated. In Hungary, however, correlations are more difficult due to the quasicontinuous character of the sedimentary records. Large ambiguities exist for the ages of the Middle Pleistocene soils, in particular for the Basaharc Double $\left(\mathrm{BD}_{1}-\mathrm{BD}_{2}\right)$ soil complex, the Basaharc Lower (BA) and the Mende Base (MB) soils. Kukla (1977) correlated the MB soil to marine isotope stage (MIS) 13, the BA soil to MIS 11, and the BD soil complex to MIS 9 and 7. The first 'absolute' ages of the MB soil were presented by Borsy et al. (1979). At Mende (Fig. 1), they dated the loess above the MB soil to $105 \pm 17 \mathrm{ka}$ using thermoluminescence (TL). In Paks (Fig. 1), the loess underlying this soil was dated to $125 \pm$ $20 \mathrm{ka}$; they concluded that the MB soil represents the last interglacial. In contrast, Wintle and Packman (1988) argued, based on their TL data for the loess underlying the Mende Upper soil (Mende felsö; $\mathrm{MF}$, also subdivided into $\mathrm{MF}_{1}$ and $\mathrm{MF}_{2}$ ), that the $\mathrm{MB}$ cannot be correlated with the last interglacial, but has to be much older. Singhvi et al. (1989) claimed that the $\mathrm{BD}_{2}$ soil (therein called $\mathrm{F}_{3}$ after Bronger (1975)) corresponds to the last interglacial. Several studies (Zöller et al., 1994; Oches and McCoy, 1995; Frechen et al., 1997; Novothny et al., 2002) have now identified the $\mathrm{MF}_{2}$ as the last interglacial palaeosol, thus placing the $\mathrm{BD}_{1}-\mathrm{BD}_{2}$ soil complex, the BA and the MB soil all in the Middle Pleistocene. Zöller et al. (1994) presented $\mathrm{TL}$ ages of $133 \pm 15 \mathrm{ka}$ (between $\mathrm{BD}_{1}$ and $\mathrm{BD}_{2}$ ) and $135 \pm 12 \mathrm{ka}$ (below $\mathrm{BD}_{2}$ ) for the sequence in Basaharc (Fig. 1). Similar ages were presented for $\mathrm{BD}_{1}$ and $\mathrm{BD}_{2}$ from Paks (Zöller and Wagner, 1990). Even though their ages were too young (possibly due to fading, i.e. an athermal signal loss which causes underestimation; cf. Wintle, 1973), Zöller et al. (1994) concluded that the $\mathrm{BD}_{1}$ and $\mathrm{BD}_{2}$ soils correspond to MIS 7. The uncertainty arising from the minimum ages, however, does not allow for an unambiguous assignment for $\mathrm{BD}_{2}$ to either MIS 7 or MIS 9.

As a result of the lack of suitable reliable dating techniques, the ages of the $\mathrm{BD}_{1}-\mathrm{BD}_{2}$ complex and the underlying soils have remained a matter of debate. Fortunately, the latest developments in luminescence dating techniques now allow for more accurate dating, even 
beyond the last glacial/interglacial cycle. Thiel et al. (2011a) presented an IRSL dating approach which makes use of a preheat at $320^{\circ} \mathrm{C}$, followed by an IR stimulation at $50^{\circ} \mathrm{C}$ and subsequent post-IR IR stimulation at $290^{\circ} \mathrm{C}$, referred to as post-IR IRSL 290 (or pIRIR 290 ). Using these settings, a natural IRSL signal from a sample from below the Brunhes-Matuyama (BM) boundary was found to be in saturation, implying that there is no or negligible anomalous fading (an athermal loss of signal with time which results in age underestimation). The stability of this signal was further investigated by Thomsen et al. (2011) and the general applicability and accuracy of this signal was tested by Buylaert et al. (2012) using an independently dated set of samples (well-bleached sediments) collected from around the world. The focus of their study was potassium-rich feldspars, while the studies of Thiel et al. (2011a, b, c) made use of polymineral fine grains, for which the IRSL signals presumably originate from all feldspars present. Tsukamoto et al. (2012) showed by comparing IRSL and TL signals from potassium and sodium feldspar with those of polymineral fine grains that at such high preheat temperatures the signal from potassium feldspar dominates; this allows one to conclude that the $\operatorname{pIRIR}_{290}$ protocol is indeed equally suitable for polymineral fine grains, which are commonly used in dating loess (cf. Roberts, 2008). This makes a very powerful dating tool available for developing chronologies of Middle Pleistocene deposits.

Here we present a pIRIR $_{290}$ based chronology for the upper part of the loess/palaeosol sequence in Paks, conventionally referred to as the 'Younger Loess Series' (e.g. Pécsi and Richter, 1996). To detect potential age overestimates due to poor signal resetting (cf. Buylaert et al., 2012), five samples are also dated using quartz blue OSL. To test whether there is significant influence on the equivalent dose using a high preheat, standard IRSL ages were obtained for the uppermost six samples. The aim is not only to solve open questions regarding the ages of the Middle Pleistocene soils in order to allow regional - and eventually global correlations but also to develop a higher resolution chronology for the Late Pleistocene; this can be used in the future for proxy studies and palaeoenvironmental reconstructions.

\section{Geological setting and logging}

Paks is located in the central Carpathian Basin close to the Danube River (Fig. 1). The entire sequence is about $60 \mathrm{~m}$ thick (Pécsi, 1979) of which about $45 \mathrm{~m}$ are exposed (Fig. 2). Classically, the 'Paks Formation' is subdivided into the 'Young Loess Series' and the 'Old Loess Series'; the latter (from base to top) includes the three rubified brown forest soils Paks Dunakömlöd (PDK) and Paks Double soils $\left(\mathrm{PD}_{1}+\mathrm{PD}_{2}\right)$, a pseudogley (Mtp; sometimes 
subdivided into $\mathrm{Mtp}_{1}+\mathrm{Mtp}_{2}$ ), and the two brown forest soils Phe (subdivided into $\mathrm{Phe}_{1}+$ $\mathrm{Phe}_{2}$ ) and MB. According to Márton (1979), the Brunhes-Matuyama (BM) boundary lies below $\mathrm{PD}_{2}$, while Sartori (2000) found it to be in the uppermost part of the $\mathrm{PD}_{2}$ soil. The 'Young Loess Series' is (from base to top) comprised of loess packages intercalated by the BA soil, the $\mathrm{BD}_{1}-\mathrm{BD}_{2}$ complex (Fig. 2), the MF soils as well as two humic soils $\left(\mathrm{h}_{1}+\mathrm{h}_{2}\right)$. Further, the Bag Tephra, underlying the BA soil, can be traced in some parts of the outcrop. According to Pouclet et al. (1999), the Bag tephra originates from the middle Italian volcanic field (Roman region); those authors suggested the Villa Senni Tuff, dated to about $351 \mathrm{ka}$, as a possible source. Further investigations by Horváth (2001) supported these findings. However, more recently, Sági et al. (2008) questioned the correlation with the Villa Senni Tuff.

Although a topographic complexity has been noted in the Paks sequence (Pécsi and Richter, 1996, and references therein) it has long been interpreted as a (quasi-) continuous record. However in many places, the MF and $h_{1}+h_{2}$ soils are eroded (or have never been present). We investigated such an incomplete sequence along the northeast-exposed wall (Fig. $2 \mathrm{~b})$; a composite $\log$ is shown in Figure 3 . The upper part $(\leq 8 \mathrm{~m})$ of the sequence is characterised by silty to sandy-silty, homogenous loess (Fig. 4a) with the exception of two thin reddish horizons (possibly reworked and/or weakly developed soils) (Fig. 4b). Two mollusc layers were found $\sim 1.5 \mathrm{~m}$ to $\sim 1.9 \mathrm{~m}$ below present day surface. Another mollusc layer could be traced at $\sim 4.3 \mathrm{~m}$ depth. The dark (chocolate) brown $\mathrm{BD}_{1}$ soil was found at $\sim 8.2-9.8 \mathrm{~m}$, and the $\mathrm{BD}_{2}$ soil at $\sim 10.7-11.4 \mathrm{~m}$. Both soils and the intercalated loess are characterised by crotovinas, especially earthworm fillings (Fig. 4c). Crotovinas are also found in the loess up to $80 \mathrm{~cm}$ below $\mathrm{BD}_{2}$. The $\sim 7 \mathrm{~m}$ thick loess between $\mathrm{BD}_{2}$ and $\mathrm{BA}$ is intercalated by two thin reddish layers (probably reworked soil material). The BA soil ( 18.4-19.1 m) is reworked (Fig. 4d), but could be clearly identified due to the underlying canary-yellow Bag tephra ( 19.4 m) (Fig. 4e) just below the BA soil.

\section{$3 \quad$ Luminescence dating}

\subsection{Sampling, preparation, and equipment}

During a field campaign in 2009, overlapping individual profiles of 1-3 $\mathrm{m}$ depth were dug in the northeast-facing loess wall (Fig. 2b; arrow). The wall of each profile was thoroughly cleaned prior to hammering metal tubes (length: $25 \mathrm{~cm}$; diameter: $3-6 \mathrm{~cm}$ ) into the sediment. The loess was sampled at intervals of $\sim 0.5 \mathrm{~m}$ in the upper part (i.e. $\leq 8 \mathrm{~m}$ depth) of the 
sequence (Fig. 3). Four more samples were taken from the loess below the BD soil complex; two of these samples are bracketing the Bag tephra (Fig. 3).

The sampling tubes were opened under subdued red light and the outer ends $(\geq 2 \mathrm{~cm}$ ) were discarded. Preparation for the polymineral fine grain fraction $(4-11 \mu \mathrm{m})$ followed Frechen et al. (1996). The samples were chemically treated with hydrochloric acid, sodium oxalate, and hydrogen peroxide; after each treatment step the material was washed using distilled water. Subsequently, the fraction 4-11 $\mu \mathrm{m}$ was obtained by repeated settling and washing using a centrifuge. The polymineral fine grains were mounted on aluminium discs from a suspension in acetone $(\sim 2 \mathrm{mg} / \mathrm{ml})$.

Quartz coarse grains $(100-150 \mu \mathrm{m})$ were obtained by automated dry-sieving the material $>11 \mu \mathrm{m}$. Density separation $\left(2.70 \mathrm{~g} / \mathrm{cm}^{-3}>\rho>2.62 \mathrm{~g} / \mathrm{cm}^{-3}\right)$ was employed in order to obtain a quartz-rich extract which was etched in hydrofluoric acid (40\%) for 1 hour. Finally, the fraction was re-sieved to remove all grains $<100 \mu \mathrm{m}$. Large aliquots (few hundreds of grains) of quartz grains were mounted on stainless steel discs using silicon spray as adhesive.

Luminescence measurements were made with an automated Ris $\emptyset$ TL/OSL reader (DA-15; Bøtter-Jensen et al., 2003) equipped with a ${ }^{90} \mathrm{Sr} /{ }^{90} \mathrm{Y}$ beta source calibrated for both quartz fine and coarse grains. The polymineral fine grains were stimulated using an array of IR light emitting diodes (LEDs) emitting at $870 \mathrm{~nm}$, and the IRSL signals were measured in the blueviolet region through a Schott BG39/Corning 7-59 filter combination (350-415 nm). The quartz OSL signals were stimulated using an array of blue LEDs emitting at $470 \mathrm{~nm}$, and the emitted luminescence measured using a UV detection window (Hoya U-340 filter; 280-380 $\mathrm{nm})$.

\subsection{Dose rate determination}

Sediment taken from immediately around the luminescence samples was dried, homogenised and packed in Marinelli-type beakers. The sealed samples were stored for at least one month to ensure equilibrium between radon and its daughters. Subsequently the concentrations of $\mathrm{U}$, Th and $\mathrm{K}$ were determined by high-resolution gamma-spectrometry at the Leibniz Institute for Applied Geophysics (LIAG). The measured concentrations were converted using the factors tabulated in Adamiec and Aitken (1998), and calculation of the cosmic radiation followed Prescott and Hutton (1994). For all samples a water content of $15 \pm$ $5 \%$ (cf. Frechen et al., 1997) was assumed; the large error on this estimate takes into account variations in water content over time. For the polymineral fraction, a mean a-value of $0.08 \pm$ 
0.01 was incorporated in the calculation of the total dose rate to the polymineral-fine grain fraction; this value is the average IRSL $\alpha$-efficiency given in Frechen et al. (1997) for the loess section in Paks.

A summary of the dose rate data is shown in Table 1 . The dose rates to the polymineral fraction range from $2.98 \pm 0.16 \mathrm{~Gy} / \mathrm{ka}$ (sample PK17) to $3.85 \pm 0.20 \mathrm{~Gy} / \mathrm{ka}$ (sample PK22), and those for the coarse grain quartz extracts from $2.33 \pm 0.10 \mathrm{~Gy} / \mathrm{ka}$ (samples PK2 and PK3) to $2.50 \pm 0.10 \mathrm{~Gy} / \mathrm{ka}$ (sample PK6).

\subsection{Post-IR IRSL measurements}

The post-IR IRSL measurements followed the protocol presented in Thiel et al. (2011a) (Table 2). In this single aliquot regenerative (SAR; Murray and Wintle, 2000) protocol, after a preheat of $320^{\circ} \mathrm{C}$ for $60 \mathrm{~s}$, the aliquots (polymineral fine grains) were stimulated with IR diodes for $200 \mathrm{~s}$ while held at $50^{\circ} \mathrm{C}$ in order to recombine the near-neighbour trap/centre pairs which are prone to fading (Thomsen et al., 2008). This first IR stimulation is followed by an IR stimulation for $200 \mathrm{~s}$ while the aliquot is held at $290^{\circ} \mathrm{C}$ (referred to as pIRIR 290 ); this elevated-temperature stimulation allows the more stable distant trap/centre pairs to recombine. The response to the test dose ( $\sim 50 \mathrm{~Gy}$ ) was measured in the same way. Prior to proceeding to the next measurement cycle, any remaining signal was removed by illumination at $325^{\circ} \mathrm{C}$ for $100 \mathrm{~s}$ (Table 2). The aliquots were measured 'one at a time'. Within each run both the pIRIR $_{290}$ and the IR signal are recorded (these are referred to as $\operatorname{IR}_{50 / 290}$ in the following), and thus data can also be presented for this signal (Table 3). However, because of the likelihood of signal instability, these data are only used for discussion of methodological aspects (e.g. effect of thermal treatment) and not for chronological interpretations.

The signal collected during the initial $2 \mathrm{~s}$ of stimulation, less a background from the last 40 $\mathrm{s}$, was used in later calculations. Representative dose response and decay curves for the pIRIR $_{290}$ signal are shown in Figure 5. Six (samples PK11-14, and PK17, PK20, PK22-23) or nine (all other samples) aliquots per sample were measured and used to calculate the mean equivalent doses. For all samples and aliquots recycling was within 5\% of unity, and recuperation below $2 \%$.

To test whether a given dose can be recovered using our protocol, a dose recovery test was applied to samples PK1 and PK5. In case of a successful test, the measured to given dose ratio should be within $10 \%$ of unity. Prior to administering a dose similar to the natural equivalent dose, three aliquots per sample were bleached for four hours in a Hönle SOL2 solar simulator. 
Three additional aliquots per sample were also bleached and used to determine the residual dose by measuring the aliquots as above; the latter measurements gave an average of $19.5 \pm$ 1.2 Gy ( $21 \pm 2$ Gy for PK1, and $18 \pm 1$ Gy for PK5). The measured to given dose ratio is 1.39 \pm 0.11 for PK1 and $1.62 \pm 0.27$ for PK5, respectively (without subtraction of the residual). When the residual is subtracted, the dose recovery tests result in marginally better measured to given ratios of $1.36 \pm 0.10$ and $1.59 \pm 0.25$. Poor dose recoveries and large residuals for the pIRIR $_{290}$ have been reported previously (e.g. Buylaert et al., 2011; Stevens et al., 2011; Thiel et al., 2011a, c; Schatz et al., 2012), although Thiel et al. (2011a and c) showed that their ages agreed well with independent age control despite unsatisfactory dose recovery tests. As a result, we are unsure of the significance of our dose recovery results.

It has also been shown that the residual measured after bleaching in a solar simulator is not the same as bleaching in sunlight (e.g. Stevens et al., 2011), and that in nature the pIRIR 290 signal can be re-set to a negligible value (e.g. Thiel et al., 2012), though the re-setting will be slower (Buylaert et al., 2012). It should also be noted that a thermal transfer of up to $20 \mathrm{~Gy}$ was observed in modern dust samples (Buylaert et al., 2011), which can have a significant influence on young (i.e. Holocene) samples.

Even though it has been shown that the pIRIR 290 signal is stable and not prone to anomalous fading (Thiel et al. 2011a; Thomsen et al., 2011; Buylaert et al., 2012), fading experiments were run of twelve of the aliquots previously used for equivalent dose measurements. A dose of $\sim 60$ Gy was administered and the $L_{x} / T_{x}$ were measured after varying storage times ranging from as short as experimentally possible up to $\sim 8$ hours. Following Auclair et al. (2003), the delays were inserted after irradiation and preheat. The mean $\mathrm{g}_{2 \text { days }}$-value is $1.1 \pm 0.7 \%(\mathrm{n}=12)$; these values are commonly found in $\mathrm{pIRIR}_{290}$ dating studies on loess, but are not thought to be representative for what is happening in nature (see discussion in Buylaert et al., 2012). For the $\mathrm{IR}_{50 / 290}$ signal the mean $\mathrm{g}_{2 \text { days }}$-value is $2.6 \pm 0.5 \%$, which is in the range of previously published values of the standard IRSL signal for Hungarian loess (e.g. Novothny et al., 2010). The ages presented in Table 3 are not corrected for fading, neither has a residual been subtracted.

\subsection{Standard IRSL measurements}

The equivalent doses of the uppermost six samples (PK1-6; polymineral fine grain fraction) were also measured using a 'standard' SAR IRSL protocol (Table 2). After a preheat of $250^{\circ} \mathrm{C}$ for $60 \mathrm{~s}$, the aliquots were stimulated with IR diodes for $100 \mathrm{~s}$ while held at $50^{\circ} \mathrm{C}$. 
The test dose ( $\sim 50 \mathrm{~Gy})$ signal was measured in the same manner. At the end of the measurement cycle, a high-temperature $\left(280^{\circ} \mathrm{C}\right)$ illumination was carried out. All aliquots were measured 'one at a time'.

For each sample, six aliquots were measured, and the signal from the initial $2 \mathrm{~s}$ of stimulation, less a background from the last $20 \mathrm{~s}$, was used for calculation. Recycling for all samples and aliquots was within $5 \%$ of unity, and recuperation was below $5 \%$. Dose recovery tests were conducted on samples PK1 and PK5. Six aliquots of each sample were bleached for four hours in a Hönle SOL2 solar simulator. Three aliquots of each sample were given a dose of $\sim 65 \mathrm{~Gy}$, and then measured in the above described manner. The other three aliquots were measured to determine the residual dose after bleaching in the solar simulator. The mean measured to given dose ratio was $0.95 \pm 0.01$ for sample PK1, and $1.04 \pm 0.06$ for sample PK5, respectively. The residuals are smaller than 2 Gy.

As for the post-IR IRSL measurements, twelve of the aliquots used for equivalent dose measurements were also used to determine $\mathrm{IR}_{50}$ fading rates. The mean $g_{2 \text { days }}$-value was $2.8 \pm$ $0.7 \%(\mathrm{n}=12)$; this is in agreement with the mean $g_{2 \text { days }}$-value measured for the $\mathrm{IR}_{50 / 290}$ signal. The ages presented in Table 3 are not corrected for fading, because they are only used to be compared with i) the uncorrected $\mathrm{IR}_{50 / 290}$ ages (and also doses) in order to discuss the effect of a higher stimulation temperature, and ii) formerly published ages not making use of fading correction.

\subsection{Blue OSL measurements}

Five samples (PK2, PK3, PK6, PK10, and PK11) were measured using quartz blue OSL. Prior to measurements, the purity of the quartz extracts was checked by means of IR depletion ratios (Duller, 2003), and all samples except PK11 were found to be sufficiently clean. A preheat of $240^{\circ} \mathrm{C}(10 \mathrm{~s})$ and a cut-heat of $200^{\circ} \mathrm{C}$ were used for dose measurements (Table 2), and the aliquots were stimulated with blue light at $125^{\circ} \mathrm{C}$ for $40 \mathrm{~s}$. At the end of each SAR cycle a high-temperature $\left(280^{\circ} \mathrm{C}\right)$ cleanout using blue stimulation for $40 \mathrm{~s}$ was used to minimise signal carry over from one measurement cycle to the next (Wintle and Murray, 2003). The suitability of this protocol was tested by means of dose recovery tests on sample PK3. Six aliquots were bleached with blue LEDs for $1000 \mathrm{~s}$, followed by a pause of $10,000 \mathrm{~s}$ and subsequent blue-light bleach for $1000 \mathrm{~s}$. The aliquots were then given a dose close to the natural, and measured using the SAR protocol described above. The mean measured to given ratio for this temperature setting is $1.00 \pm 0.02(n=6)$; it should be noted that there was no 
significant dependency of the measured to given dose ratio on the preheat temperature, as long as a preheat $<300^{\circ} \mathrm{C}$ is used (Fig. 6).

Because sample PK11 suffered from slight feldspar contamination a double SAR protocol (e.g. Banerjee et al., 2001; Roberts and Wintle, 2003) was employed. The settings were the same as above, but included IR stimulation at $125^{\circ} \mathrm{C}$ for $100 \mathrm{~s}$ immediately prior to blue stimulation (Table 2). A dose recovery experiment using the same bleaching settings as above resulted in a mean measured to given dose ratio of $0.97 \pm 0.04(n=6)$.

For all quartz measurements, equivalent doses were calculated using the signal from the initial $0.2 \mathrm{~s}$ of the stimulation curve, less a background from the subsequent $1 \mathrm{~s}$ (early background subtraction; Cunningham and Wallinga, 2010); this is intended to reduce the medium component. Twelve (PK11) or 18 aliquots (all other samples) were measured to calculate an average equivalent dose for each sample. For all aliquots and samples, recycling was within $10 \%$, and recuperation was $<5 \%$. The resulting equivalent doses are summarised in Table 3. An example of a dose response curve (single exponential fitting) and decay curve for sample PK2 is shown in Figure 7. This behaviour is representative for all samples except PK11, which was found to be in saturation $\left(D_{e}>2 * D_{0}\right.$; Wintle and Murray, 2006); a minimum age is given for this sample (Table 3).

\section{$4 \quad$ Results and Discussion}

\subsection{The last glacial cycle}

Previous luminescence dating studies have revealed that the majority of the last interglacial/glacial cycle is not preserved in most parts of Hungary (Wintle and Packmann, 1988; Frechen et al., 1997; Novothny et al., 2002, 2009, 2010). Our data support this conclusion (Table 3 and Fig. 8). For the last glacial cycle, the pIRIR 290 ages (on which our chronology is based) range from $25 \pm 2 \mathrm{ka}$ (PK1) to $38 \pm 3 \mathrm{ka}$ (PK10); all other samples are older than $130 \mathrm{ka}$, i.e. older than the last interglacial. Most of the ages fall into MIS 3; the four uppermost samples are at the transition to MIS 2, which is defined here as the period from the onset of the Greenland Interstadial (GI-) $3(27.8 \pm 0.4 \mathrm{~b} 2 \mathrm{k}$ (=before year $2000 \mathrm{AD})$ ) to the termination of the Younger Dryas (following Svensson et al., 2006).

Frechen et al. (1997) obtained multiple aliquot IRSL ages ranging from $14.8 \pm 1.4 \mathrm{ka}$ to $19.7 \pm 1.7 \mathrm{ka}$ (regenerative protocol) for the upper part of the section (down until the discontinuity; their Fig. 5). These ages showed some inversions, while the IRSL ages using the additive protocol were stratigraphically consistent, ranging from $13.4 \pm 1.4$ ka to $19.2 \pm$ 
$1.7 \mathrm{ka}$. They concluded that the uppermost loess was deposited after the Last Glacial Maximum (LGM). According to Svensson et al. (2006), the LGM is the cold period between GI-2 and GI-3, i.e. it ranged from $\sim 27.5$ to $\sim 23 \mathrm{ka}$ (cf. their Figs. 1 and 3). However none of Frechen et al's IRSL ages were corrected for anomalous fading, and in contrast our ages for the uppermost samples are older; they are all consistent with the LGM, and none of our ages fall into the time after this cold period.

In addition to the IRSL ages, Frechen et al. (1997) also presented TL ages, which ranged from $26.5 \pm 8.7 \mathrm{ka}$ to $55.3 \pm 5.4 \mathrm{ka}$ (regenerative protocol). It has to be noted that the ages were stratigraphically inconsistent and that errors were very large. The TL ages obtained using the additive method ranged from $18.5 \pm 12.3 \mathrm{ka}$ to $54.8 \pm 6.6 \mathrm{ka}$, again with several age inversions; age correction for fading was not applied. Because of the stratigraphic inconsistencies, Frechen et al. (1997) concluded that the TL ages are not reliable; they argued that the cause for the unreliability is insufficient bleaching prior to deposition due to proximity to the loess source.

In an aeolian setting, it is difficult to believe that incomplete re-setting of the luminescence signal is the origin of erroneous age estimates (unless transport and deposition took place in darkness). If the loess was indeed not properly bleached prior to deposition, it would affect the pIRIR 290 signal in a similar manner because it has been shown that this signal is far more difficult to bleach than the conventional IRSL signal and, even to a greater extend, than the quartz OSL signal (Buylaert et al., 2011, 2012). In order to check whether the young loess in Paks is affected by poor bleaching, we compared the pIRIR $_{290}$ ages with the ages obtained from blue OSL on coarse grain quartz (Fig. 9). The ages for the younger four samples are in very good agreement; the quartz signal from sample PK11 is in saturation, resulting in a minimum age of $>80 \mathrm{ka}$. The OSL minimum age confirms the discontinuity in the sequence. The very good agreement for the younger samples also suggests that the pIRIR 290 residual signal measured is probably not representative of any residual in nature; if it were to be, the pIRIR $_{290}$ age would overestimate the OSL age (a residual of $\sim 20$ Gy translates to about $\sim 6.5$ ka). Because the quartz OSL and polymineral pIRIR 290 ages are in agreement, insufficient bleaching of the pIRIR 290 signal can be excluded (cf. Murray et al., 2012). It is more likely that the IRSL ages presented in Frechen et al. (1997) underestimate due to anomalous fading; this is supported by our $\operatorname{IR}_{50 / 290}$ age estimates (Table 3 ), which all underestimate the pIRIR 290 (and quartz OSL) ages (Fig. 9). 
We also measured 'standard' SAR IRSL for the uppermost six samples (Table 3) using preheat of $250^{\circ} \mathrm{C}$. The ages are similar to the $\mathrm{IR}_{50}$ data obtained as part of the pIRIR 290 (Fig. 10); there is no systematic trend in these data, and the uncorrected ages based on both $\mathrm{IR}_{50}$ data sets point to deposition mainly after the LGM, agreeing with Frechen et al. (1997). However, we are confident that our IR $_{50}$ ages underestimate both quartz and pIRIR 290 ages because of fading and so we deduce that the ages presented in Frechen et al. (1997) are also underestimated.

We conclude that the last glacial loess preserved at this site was deposited prior to or during the LGM, but no MIS 4 loess or MIS 5 soil is found at this part of the outcrop. Since the uppermost meter was not sampled (cf. Fig. 3), we cannot draw any conclusion on whether there is any loess deposited after the LGM. If there is any, it must now be of limited thickness, most likely due to erosion and agriculture activity.

Loess deposition during MIS 3 has been observed at other sites in Hungary (e.g. Tokaj; Schatz et al., 2012), although this stage is usually characterised by soil formation. In Albertirsa (Novothny et al., 2002) the upper soil $\left(\mathrm{MF}_{1}\right.$ soil, following the 'classical' nomenclature) was IRSL (MAAD) dated to between $37.1 \pm 4.2 \mathrm{ka}$ and $29.1 \pm 5.2 \mathrm{ka}$; a humic horizon in the younger part was dated to $21.7 \pm 4.8 \mathrm{ka}$. None of these ages are corrected for fading, and thus an age underestimate is, in our view, likely. Schatz et al. (2012) found two MIS 3 soils; the sediment in which the lower soil formed was pIRIR 290 dated to $57 \pm 5 \mathrm{ka}$ and the loess below the upper one to $39 \pm 4 \mathrm{ka}$ and the loess above to $30 \pm 3 \mathrm{ka}$, respectively. In Süttő, one light brown palaeosol was found in the MIS 3 sequence (Novothny et al., 2011). For Süttő, the old, non-fading corrected ages presented in Novothny et al. (2009) imply thick ( $\sim 5 \mathrm{~m}$ ) MIS 2 loess. The new ages (Novothny et al., 2011; their Fig. 2) show that these formerly published age estimates have to be partly revised; considerable loess deposition took place during MIS 3 and/or close to the transition to MIS 2. This would be in concordance with our observations at Paks. Nevertheless, the absence of palaeosols in Paks during MIS 3 needs to be explained. One possible explanation is erosion; the reddish (reworked) layer (cf. Fig, 3) is a remnant of an eroded soil. An alternative explanation is that our sampling site sits in a topographic position which functioned as local sediment trap with higher accumulation rates preventing significant soil formation. The complex topography with several palaeodepressions along the loess wall in the brickyard has already been pointed out in early works (Pécsi, 1979). This interpretation would be similar to the topographically controlled sediment trap described in Thiel et al. (2011d); luminescence dating at Langenlois, Lower Austria 
revealed an exceptionally thick MIS 3 sequence with only few humic horizons, and no significant soil formation. This shows not only the importance of topography, but also the general complexity of MIS 3.

\subsection{The Middle Pleistocene}

There clearly is a discontinuity in the loess/palaeosol sequence, separating the Middle from the Late Pleistocene (Fig. 8). This discontinuity has also been observed by others (e.g. Oches and McCoy, 1995; Frechen et al., 1997) based both on field observations and on dating results. Based on amino acid racemisation, Oches and McCoy (1995) concluded that most of the Young Loess Series formed during the Middle Pleistocene; this is in accordance with our dating results - sample PK10 was dated to $38 \pm 3 \mathrm{ka}$, but the underlying sample PK11 gave an age of $199 \pm 27 \mathrm{ka}$. All other loess samples above the $\mathrm{BD}_{1}-\mathrm{BD}_{2}$ soil complex were dated to between $224 \pm 21 \mathrm{ka}$ (sample PK12) and $259 \pm 27 \mathrm{ka}$ (sample PK14). Within errors, all ages are identical, although there is a clear trend for the ages to increase with depth. Again, the age estimates point to MIS 7; if the errors are taken into account, the end of MIS 6 cannot be ruled out. These ages suggest little loess deposition during MIS 6; this seems unlikely given that this period is thought to be a prolonged cold stage giving thick loess deposition (cf. Thiel et al., 2011b). A simple explanation for the lack of MIS 6 loess at Paks would be erosion, similar to the MIS 2 loess. We do not consider significant age overestimation likely, given the good agreement for the younger material with quartz OSL ages. If there is no overestimate for the younger samples, it is difficult envisage a significant age overestimate resulting from poor resetting prior to deposition; the larger the equivalent dose, the less likely it is that a residual dose at deposition is of significance.

Nevertheless, field observations do show that parts of the loess above the $\mathrm{BD}_{1}-\mathrm{BD}_{2}$ soil complex was reworked (Figs. $4 \mathrm{~b}$ and 8 ); this post-depositional process could cause a slight age overestimate. Further, several crotovinas were found (Figs. 4c and 8); the borrowing animals mix the sediment. Therefore, the MIS 7 ages for the loess above the BD soil complex may include a small degree of age overestimation, so that the loess was actually deposited in MIS 6.

The loess below the $\mathrm{BD}_{1}-\mathrm{BD}_{2}$ soil complex was dated to $287 \pm 36 \mathrm{ka}$ (sample PK17), i.e. MIS 8. No signs of reworking were observed, and thus no significant age overestimate is anticipated. We deduce that both $\mathrm{BD}_{1}$ and $\mathrm{BD}_{2}$ developed during MIS 7, as was suggested previously by Zöller et al. (1994). Bronger (2003) has correlated the F3 soil (=BD) with MIS 
5, and the F4 soil (=BA soil) with MIS 7; this correlation was based on TL ages, and can now be ruled out with some confidence. It also appears unlikely that $\mathrm{BD}_{2}$ corresponds to MIS 9 , as suggested by e.g. Kukla (1977). Based on magnetic susceptibility data presented in Sartori et al. (1999), Marković et al. (2011) have correlated the $\mathrm{BD}_{1}-\mathrm{BD}_{2}$ soil complex with the two pronounced warm peaks during MIS 7 (their Fig. 6). They further correlated the BA soil with MIS 9. Our ages (Table 3 and Fig. 8) might allow for the same conclusion; however, the pIRIR $_{290}$ signal approaches saturation and it is not clear how accurate ages close to saturation are. We therefore give minimum ages for the lowermost three samples (cf. Table 3). Given the numerous discontinuities found in Hungarian loess/palaeosol sequences from the last glacial period, it would be unwise to assume that the older loess represents a continuous record. Given the reddish layers (possibly reworked material) in the loess below the $\mathrm{BD}_{1}-\mathrm{BD}_{2}$ soil complex (Fig. 8), we consider it likely that part of the Middle Pleistocene record is missing at the Paks site.

\section{Conclusions}

We made use of the latest luminescence dating technique $\left(p I R I R_{290}\right)$ to date the loess/palaeosol sequence at Paks, central Hungary. For younger samples, the pIRIR 290 ages could be compared to quartz blue OSL ages in order to address the question of incomplete signal re-setting. The blue OSL and pIRIR 290 ages agree well, implying that the pIRIR $_{290}$ ages do not inherently overestimate. Any discrepancy with published data most likely originates from athermal signal loss (anomalous fading); this conclusion is supported by our uncorrected 'standard' IRSL ages; these significantly underestimate the blue OSL and pIRIR 290 ages.

Our age estimates point to pre-LGM and LGM loess deposition at Paks, with most of the sedimentation taking place during MIS 3. No MIS 4 and MIS 5 loess was found. Clearly, the loess/palaeosol sequence at Paks is not a continuous record, a conclusion in agreement with field observations showing reworking and a discontinuity in the sequence.

The Basaharc Double soil complex can be correlated with MIS 7. It remains an open question whether the Basaharc Lower soil corresponds to MIS 9 or an older interglacial because the pIRIR 290 signal approaches saturation; any age estimate close to saturation may not be accurate. Future research will have to focus on a better understanding of the saturation and thus dating limit for $\mathrm{pIRIR}_{290}$.

\section{Acknowledgements}


This work was funded by the German Academic Exchange Service (DAAD, project no. 50024670). We are indebted to the Hungarian Scientific Research Fund (grant OTKA 68219). E.H. thanks the Bolyai Postdoctoral Fellowship program. We are grateful to the Hungarian students for their help during field work. Sonja Riemenschneider is thanked for the preparation of the luminescence samples. Ágnes Novothny is thanked for fruitful discussions and improvements on an earlier version of the manuscript. Andrew Murray is thanked for language improvements.

\section{References}

Adamiec, G., Aitken, M.J., 1998. Dose-rate conversion factors: update. Ancient TL 16, 37-50.

Auclair, M., Lamothe, M., Huot, S., 2003. Measurement of anomalous fading for feldspar IRSL using SAR. Radiation Measurements 37, 487-492.

Banerjee, D., Murray, A.S., Bøtter-Jensen, L., Lang, A., 2001. Equivalent dose determination from a single aliquot of polymineral fine grains. Radiation Measurements 33, 73-94.

Borsy, Z., Félszerfalvi, J., Szabó, P.P., 1979. Thermoluminescence dating of several layers of the loess sequence at Paks and Mende (Hungary). Acta Geologica Academiae Scientiarum Hungaricae 22, 451-459.

Bøtter-Jensen, L., Andersen, C.E., Duller, G.A.T., Murray, A.S., 2003. Developments in radiation, stimulation and observation facilities in luminescence measurements. Radiation Measurements 37, 535-541.

Bronger, A., 1975. Paläoböden als Klimazeugen - dargestellt an Löß-Boden-Abfolgen des Karpartenbeckens. Quaternary Science Journal (E\&G) 26, 131-154.

Bronger, A., 2003. Correlations of loess-paleosol sequences in East and Central Asia with SE Central Europe: towards a continental Quaternary pedostratigraphy and paleoclimatic history. Quaternary International 106/107, 11-31.

Buylaert, J.-P., Thiel, C., Murray, A.S., Vandenberghe, D.A.G., Yi, S., Lu, H., 2011. IRSL and post-IR IRSL residual doses recorded in modern dust samples from the Chinese Loess Plateau. Geochronometria 38, 432-440.

Buylaert J.-P., Jain, M., Murray, A.S., Thomsen, K.J., Thiel, C., Sohbati, R., 2012. A robust feldspar luminescence dating method for Middle and Late Pleistocene sediments. Boreas 41, 435-451. 
Cunningham, A.C., Wallinga, J., 2010. Selection of integration time intervals for quartz OSL decay curves. Quaternary Geochronology 5, 657-666.

Duller, G.A.T., 2003. Distinguishing quartz and feldspar in single grain luminescence measurements. Radiation Measurements 37, 161-165.

Fitzsimmons, K.E., Marković, S.B., Hambach, U., 2012. Pleistocene environmental dynamics recorded in the loess of the middle and lower Danube basin. Quaternary Science Reviews 41, 104-118.

Frechen, M., Schweitzer, U., Zander, A., 1996. Improvements in sample preparation for the fine grain technique. Ancient TL 14, 15-17.

Frechen, M., Horváth, E., Gábris, G., 1997. Geochronology of Middle and Upper Pleistocene Loess Sections in Hungary. Quaternary Research 48, 291-312.

Horváth, E., 2001. Marker horizons in the loesses of the Carpathian Basin. Quaternary International 76/77, 157-163.

Kukla, G.J., 1977. Pleistocene Land-Sea correlations 1. Europe. Earth Science Reviews 13, 307-374.

Kukla, G.J., 1987. Loess stratigraphy in Central China. Quaternary Science Reviews 6, 191219.

Marković, S.B., Bokhorst, M.P., Vandenberghe, J., McCoy, W.D., Oches, E.A., Hambach, U., Gaudenyi, T., Jovanović, M., Zöller, L., Stevens, T., Machalett, B., 2008. Late Pleistocene loess-palaeosol sequences in the Vojvodina region, north Serbia. Journal of Quaternary Science 23, 73-84.

Marković, S.B., Hambach, U., Stevens, T., Kukla, G.J., Heller, F., McCoy, W.D., Oches, E.A., Buggle, B., Zöller, L., 2011. The last million years recorded at the Stari Slankamen (Northern Serbia) loess-palaeosol sequence: revised chronostratigraphy and long-term environmental trends. Quaternary Science Reviews 30, 1142-1154.

Márton, P., 1979. Paleomagnetism of the Paks brickyard exposures. Acta Geologica Academiae Scientiarum Hungaricae 22, 443-449.

Murray, A.S., Wintle, A.G., 2000. Luminescence dating of quartz using an improved singlealiquot regenerative-dose protocol. Radiation Measurements 32, 57-73.

Murray, A.S., Wintle, A.G., 2003. The single aliquot regenerative dose protocol: potential for improvements in reliability. Radiation Measurements 37, 377-381. 
Murray, A.S., Thomsen, K.J., Masuda, N., Buylaert, J.P., Jain, M., 2012. Identifying wellbleached quartz using the different bleaching rates of quartz and feldspar luminescence signals. Radiation Measurements 47, 688-695.

Novothny, A., Horváth, E., Frechen, M., 2002. The loess profile of Albertirsa, Hungary Improvements in loess stratigraphy by luminescence dating. Quaternary International 95/96, 155-163.

Novothny, Á., Frechen, M., Horváth, E., Bradák, B., Oches, E.A., McCoy, W., Stevens, T., 2009. Luminescence and amino acid racemization chronology and magnetic susceptibility record of the loess-paleosol sequence at Süttö, Hungary. Quaternary International 198, 62-76.

Novothny, Á., Frechen, M., Horváth, E., Krbetschek, M., Tsukamoto, S., 2010. Infrared stimulated luminescence and radiofluorescence dating of aeolian sediments from Hungary. Quaternary Geochronology 5, 114-119.

Novothny, Á., Frechen, M., Horváth, E., Wacha, L., Rolf, C., 2011. Investigating the penultimate and last glacial cycles of the Süttö loess section (Hungary) using luminescence dating, high-resolution grain size, and magnetic susceptibility data. Quaternary International 234, 75-85.

Oches, E.A., McCoy, W.D., 1995. Aminostratigraphic Evaluation of Conflicting Age Estimates for the "Young Loess" of Hungary. Quaternary Research 44, 160-170.

Pécsi, M., 1979. Lithostratigraphical subdivison of the loess profiles at Paks. Acta Geologica Academiae Scientiarum Hungaricae 22, 409-418.

Pécsi, M., Richter, G., 1996. Löss. Herkunft - Gliederung - Landschaften. Annals of Geomorphology 98, 391 pp.

Prescott, J.R., Hutton, J.T., 1994. Cosmic ray contributions to dose rates for luminescence and ESR dating: large depths and long-term variations. Radiation Measurements 23, 497 500 .

Pouclet, A., Horváth, E., Gábris, G., Juvigne, E., 1999. The Bag Tephra, a widespread tephrochronological marker in Middle Europe: chemical and mineralogical investigations. Bulletin Volcanology 60, 265-272.

Roberts, H.M., 2008. The development and application of luminescence dating to loess deposits: a perspective on the past, present and future. Boreas 37, 483-507. 
Roberts, H.M., Wintle, A.G., 2003. Luminescence sensitivity changes of polymineral fine grains during IRSL and [post-IR] OSL measurements. Radiation Measurements 37, 661-671.

Sági, T., Kiss, B., Bradák, B., Harangi, Sz., 2008. Középso-pleisztocén löszben eloforduló vulkáni képzodmények Magyarországon: terepi és petrográfiai jellemzok. Földtani Közlöny 138, 297-310.

Sartori, M., 2000. The Quaternary climate in loess sediments: Evidence from rock and mineral magnetic and geochemical analysis. PhD thesis, Eidgenössische Technische Hochschule Zürich, $231 \mathrm{pp}$.

Sartori, M., Heller, F., Forster, T., Borkovec, M., Hamman, J., Vincent, E., 1999. Magnetic properties of loess grain size fractions from the section at Paks (Hungary). Physics of the Earth and Planetary Interiors 116, 53-64.

Schatz, A.-K., Buylaert, J.-P., Murray, A., Stevens, T., Scholten, T., 2012. Establishing a luminescence chronology for a palaeosol-loess profile at Tokaj (Hungary): a comparison of quartz OSL and polymineral IRSL signals. Quaternary Geochronology $10,68-74$.

Singhvi, A.K., Bronger, A., Sauer, W., Pant, R.K., 1989. Thermoluminescence dating of loess-paleosol sequences in the Carpathian Basin (East-central Europe): A suggestion for a revised chronology. Chemical Geology 73, 307-317.

Stevens, T., Marković, S.B., Zech, M., Hambach, U., Sümegi, P., 2011. Dust deposition and climate in the Carpathian Basin over an independently dated last glacial-interglacial cycle. Quaternary Science Reviews 30, 662-681.

Svensson, A., Andersen, K.K., Bigler, M., Clausen, H.B., Dahl-Jensen, D., Davies, S.M., Johnsen, S.J., Muscheler, R., Rasmussen, S.O., Röthlisberger, R., Steffensen, J.P., Vinther, B.M., 2006. The Greenland Ice Core Chronology 2005, 15-42 ka. Part 2: Comparison to other records. Quaternary Science Reviews 25, 3258-3267.

Thiel, C., Buylaert, J.-P., Murray, A., Terhorst, B., Hofer, I., Tsukamoto, S., Frechen, M. 2011a. Luminescence dating of the Stratzing loess profile (Austria) - Testing the potential of an elevated temperature post-IR IRSL protocol. Quaternary International 234, 23-31. 
Thiel, C., Buylaert, J.-P., Murray, A.S., Terhorst, B., Tsukamoto, S., Frechen, M., Sprafke, T., 2011b. Investigating the chronostratigraphy of prominent palaeosols in Lower Austria using post-IR IRSL dating. Quaternary Science Journal (E\&G) 60, 137-152.

Thiel, C., Buylaert, J.-P., Murray, A.S., Tsukamoto, S., 2011c. On the applicability of post-IR IRSL dating to Japanese loess. Geochronometria 38, 369-378.

Thiel, C., Terhorst, B., Jaburová, I., Buylaert, J.-P., Murray, A.S., Fladerer, F.A., Damm, B., Frechen, M., Ottner, F., 2011d. Sedimentation and erosion processes in Middle to Late Pleistocene sequences exposed in the brickyard of Langenlois/Lower Austria. Geomorphology 135, 295-307.

Thiel, C., Buylaert, J.-P., Murray, A.S., Elmejdoub, N., 2012. A comparison of TT-OSL and post-IR IRSL dating of coastal deposits on Cap Bon peninsula, north-eastern Tunisia. Quaternary Geochronology 10, 209-217.

Thomsen, K.J., Murray, A.S., Jain, M., 2011. Stability of IRSL signals from sedimentary Kfeldspar samples. Geochronometria 38, 1-13.

Tsukamoto, S., Jain, M., Murray, A., Thiel, C., Schmidt, E., Wacha, L., Dohrmann, R., Frechen, M., 2012. A comparative study of the luminescence characteristics of polymineral fine grains and coarse grained K-, and Na-rich feldspars. Radiation Measurements 47, 903-908.

Wallinga, J., Murray, A., Wintle, A., 2000. The single-aliquot regenerative-dose (SAR) protocol applied to coarse-grain feldspar. Radiation Measurements 32, 529-533.

Wintle, A.G., 1973. Anomalous fading of thermoluminescence in minerals. Nature 245, 143 144.

Wintle, A.G., Packman, S.C., 1988. Thermoluminescence ages for three sections in Hungary. Quaternary Science Reviews 7, 315-320.

Wintle, A.G., Murray, A.S., 2006. A review of quartz optically stimulated luminescence characteristics and their relevance in single-aliquot regeneration dating protocols. Radiation Measurements 41, 369-391.

Zöller, L., Wagner, G.A., 1990. Thermoluminescence dating of loess - recent developments. Quaternary International 7/8, 119-128.

Zöller, L., Oches, E.A., McCoy, W.D., 1994. Towards a revised chronostratigraphy of loess in Austria with respect to key sections in the Czech Republic and in Hungary. Quaternary Geochronology (Quaternary Science Reviews) 13, 465-472. 


\section{Figure Captions}

Figure 1: Map of Hungary. Paks (star) is located in southern central Hungary close to the Danube River. Basaharc and Mende (triangles) are type localities for Middle Pleistocene soils referred to in this study.

Figure 2: Photographs of the brickyard in Paks. a) Main wall investigated by e.g. Pécsi (1979)

b) parts of the main wall and outcrop (arrow); the Danube River can be seen in the background. $\mathrm{PD}_{1}+\mathrm{PD}_{2}=$ Paks Double soil, $\mathrm{B} / \mathrm{M}$ boundary = Brunhes $/$ Matuyama boundary $(\sim 780 \mathrm{ka}) \mathrm{MB}=$ Mende Base soil; $\mathrm{BA}=$ Basaharc Lower soil; $\mathrm{BD}_{1}+\mathrm{BD}_{2}=$ Basaharc Double soil complex.

Figure 3: Composite profile of the $\sim 20 \mathrm{~m}$ thick loess-palaeosol section investigated in this study.

Figure 4: Photographs of some sedimentary and pedogenetic features of the loess/palaeosol sequence in Paks. a) Homogenous loess in the upper part of the section; macroscopically, no differentiation can be made, b) reddish layer at a depth of $6.4 \mathrm{~m}, \mathrm{c}$ ) chocolate brown soil $\left(\mathrm{BD}_{2}\right)$; the over- and underlying loess is characterised by crotovina, d) BA soil at a depth of $18.5 \mathrm{~m}$, e) canary-yellow Bag tephra.

Figure 5: pIRIR $_{290}$ dose response curves and decay curves (insets) for samples PK 2 (a)) and PK10 (b)); for the latter regenerated doses up to 1300 Gy were used to better define the dose response at higher doses. The triangles are the recycling points, and the squares show the sensitivity corrected IRSL of the natural.

Figure 6: Results of the dose recovery tests with varying preheat temperatures. For all preheat temperatures (except $300^{\circ} \mathrm{C}$ ), the measured to given dose ratio is within $10 \%$ of unity.

Figure 7: Blue OSL dose response curve and decay curve (inset) for sample PK 2. The curve was fitted using a single exponential. The triangle is the recycling point, and the square shows the sensitivity corrected natural OSL signal.

Figure 8: Log of the composite profile and pIRIR $_{290}$ ages. The grey shaded areas show the MIS 3, 5, 7, and 9, respectively. The three lowermost age estimates have to be interpreted as minimum ages because the $\mathrm{pIRIR}_{290}$ signal is close to saturation. Note the break in the age axis.

Figure 9: Uncorrected standard IRSL ages plotted against uncorrected IRSL50/290 ages. The dashed line is the $1: 1$ line, and the dotted lines are $\pm 10 \%$. 
Figure 10: pIRIR 290 ages plotted against uncorrected IRSL $_{50 / 290}$ ages (dark circles) and blue OSL ages, respectively (light circles). The dashed line is the 1:1 line, and the dotted lines are $\pm 10 \%$. Note the logarithmic scale.

\section{Table Captions}

Table 1: Summary of the burial depths and radionuclide concentrations used to calculate the total quartz and polymineral fine grain (p.f.g.) dose rates. For all samples a water content of $15 \pm 5 \%$ was used. The depths given are the sampling depths in $\mathrm{m}$ below present day surface.

Table 2: Dating protocols used in this study: (A) SAR pIRIR 290 (Thiel et al., 2011a), (B) SAR 'standard' IRSL (Wallinga et al., 2000), (C) SAR blue OSL (Murray and Wintle, 2003), and (D) double SAR blue OSL (e.g. Roberts and Wintle, 2003).

Table 3: Equivalent doses (Gy) and ages (ka) for the quartz OSL, IRSL and post-IR IRSL signals. For details see text. 
Table 1: Summary of the burial depths and radionuclide concentrations used to calculate the total quartz and polymineral fine grain (pfg.) dose rates. For all samples a water content of $15 \pm 5 \%$ was used. The depths given are the sampling depths below present day surface.

\begin{tabular}{|c|c|c|c|c|c|c|c|c|}
\hline Field ID & Lab ID & $\begin{array}{l}\text { Depth } \\
{[\mathrm{cm}]}\end{array}$ & $\begin{array}{c}\mathrm{K} \\
{[\%]}\end{array}$ & $\begin{array}{c}\text { Th } \\
{[\mathrm{ppm}]}\end{array}$ & $\begin{array}{c}\mathrm{U} \\
{[\mathrm{ppm}]}\end{array}$ & $\begin{array}{l}\text { Cosmic dose } \\
{[\mathrm{Gy} / \mathrm{ka}]}\end{array}$ & $\begin{array}{c}\text { Total dose rate quartz } \\
{[\mathrm{Gy} / \mathrm{ka}]}\end{array}$ & $\begin{array}{l}\text { Total dose rate pfg. } \\
{[\mathrm{Gy} / \mathrm{ka}]}\end{array}$ \\
\hline PK1 & 1881 & 110 & $1.22 \pm 0.01$ & $10.13 \pm 0.06$ & $3.13 \pm 0.03$ & $0.185 \pm 0.018$ & - & $3.15 \pm 0.16$ \\
\hline PK2 & 1882 & 220 & $1.27 \pm 0.01$ & $10.67 \pm 0.07$ & $3.24 \pm 0.03$ & $0.159 \pm 0.016$ & $2.33 \pm 0.10$ & $3.25 \pm 0.17$ \\
\hline PK3 & 1883 & 270 & $1.29 \pm 0.02$ & $10.01 \pm 0.09$ & $3.41 \pm 0.04$ & $0.149 \pm 0.015$ & $2.33 \pm 0.10$ & $3.25 \pm 0.17$ \\
\hline PK4 & 1884 & 320 & $1.35 \pm 0.02$ & $10.26 \pm 0.10$ & $3.37 \pm 0.06$ & $0.140 \pm 0.014$ & - & $3.30 \pm 0.16$ \\
\hline PK5 & 1885 & 410 & $1.27 \pm 0.02$ & $9.32 \pm 0.10$ & $3.35 \pm 0.05$ & $0.125 \pm 0.013$ & - & $3.13 \pm 0.18$ \\
\hline PK6 & 1886 & 460 & $1.45 \pm 0.02$ & $10.81 \pm 0.08$ & $3.57 \pm 0.04$ & $0.118 \pm 0.012$ & $2.50 \pm 0.10$ & $3.48 \pm 0.18$ \\
\hline PK7 & 1887 & 510 & $1.38 \pm 0.01$ & $10.98 \pm 0.07$ & $3.28 \pm 0.03$ & $0.111 \pm 0.011$ & - & $3.33 \pm 0.17$ \\
\hline PK8 & 1888 & 560 & $1.34 \pm 0.01$ & $11.34 \pm 0.06$ & $3.28 \pm 0.03$ & $0.104 \pm 0.010$ & - & $3.33 \pm 0.17$ \\
\hline PK9 & 1889 & 610 & $1.33 \pm 0.01$ & $11.12 \pm 0.06$ & $3.29 \pm 0.03$ & $0.098 \pm 0.010$ & $2.35 \pm 0.10$ & $3.29 \pm 0.17$ \\
\hline PK10 & 1890 & 660 & $1.48 \pm 0.02$ & $10.82 \pm 0.11$ & $3.45 \pm 0.07$ & $0.093 \pm 0.009$ & $2.48 \pm 0.10$ & $3.44 \pm 0.17$ \\
\hline PK11 & 1891 & 710 & $1.45 \pm 0.01$ & $12.20 \pm 0.06$ & $3.18 \pm 0.02$ & $0.088 \pm 0.009$ & - & $3.45 \pm 0.18$ \\
\hline PK12 & 1892 & 740 & $1.62 \pm 0.01$ & $11.41 \pm 0.10$ & $3.38 \pm 0.05$ & $0.085 \pm 0.009$ & - & $3.59 \pm 0.18$ \\
\hline PK13 & 1893 & 770 & $1.51 \pm 0.03$ & $11.70 \pm 0.06$ & $3.24 \pm 0.03$ & $0.082 \pm 0.008$ & - & $3.47 \pm 0.17$ \\
\hline PK14 & 1894 & 810 & $1.52 \pm 0.01$ & $12.23 \pm 0.06$ & $3.19 \pm 0.02$ & $0.079 \pm 0.008$ & - & $3.51 \pm 0.18$ \\
\hline PK17 & 1898 & 1220 & $1.29 \pm 0.01$ & $10.63 \pm 0.03$ & $2.68 \pm 0.01$ & $0.052 \pm 0.005$ & - & $2.98 \pm 0.16$ \\
\hline PK20 & 1901 & 1550 & $1.54 \pm 0.01$ & $12.68 \pm 0.06$ & $2.94 \pm 0.03$ & $0.035 \pm 0.004$ & - & $3.45 \pm 0.17$ \\
\hline PK22 & 1903 & 1930 & $1.62 \pm 0.01$ & $14.67 \pm 0.07$ & $3.45 \pm 0.03$ & $0.027 \pm 0.003$ & - & $3.85 \pm 0.20$ \\
\hline PK23 & 1904 & 1980 & $1.61 \pm 0.01$ & $13.28 \pm 0.06$ & $3.30 \pm 0.03$ & $0.026 \pm 0.003$ & - & $3.66 \pm 0.18$ \\
\hline
\end{tabular}


Table 2: Dating protocols used in this study: (A) SAR post-IR IRSL 290 (Thiel et al., 2011a), (B) 'standard' SAR IRSL (Wallinga et al., 2000), (C) SAR blue OSL (Murray and Wintle, 2003), and (D) double SAR blue OSL (e.g. Roberts and Wintle, 2003).

\begin{tabular}{|c|c|c|c|c|}
\hline (A) post-IR IRSL 290 & (B) 'standard' IRSL & (C) blue OSL & (D) double SAR & Observed \\
\hline Dose & Dose & Dose & Dose & \\
\hline Preheat $\left(320^{\circ} \mathrm{C}, 60 \mathrm{~s}\right)$ & Preheat $\left(250^{\circ} \mathrm{C}, 60 \mathrm{~s}\right)$ & Preheat $\left(240^{\circ} \mathrm{C}, 10 \mathrm{~s}\right)$ & Preheat $\left(240^{\circ} \mathrm{C}, 10 \mathrm{~s}\right)$ & \\
\hline $\operatorname{IRSL}\left(50^{\circ} \mathrm{C}, 200 \mathrm{~s}\right)$ & & & & $\operatorname{Lx}_{(50 / 290)}$ \\
\hline IRSL $\left(290^{\circ} \mathrm{C}, 200 \mathrm{~s}\right)$ & $\operatorname{IRSL}\left(50^{\circ} \mathrm{C}, 100 \mathrm{~s}\right)$ & OSL $\left(125^{\circ} \mathrm{C}, 40 \mathrm{~s}\right)$ & $\begin{array}{l}\operatorname{IRSL}\left(125^{\circ} \mathrm{C}, 100 \mathrm{~s}\right) \\
\text { OSL }\left(125^{\circ} \mathrm{C}, 40 \mathrm{~s}\right)\end{array}$ & Lx \\
\hline Test dose & Test dose & Test dose & Test dose & \\
\hline Preheat $\left(320^{\circ} \mathrm{C}, 60 \mathrm{~s}\right)$ & Preheat $\left(250^{\circ} \mathrm{C}, 60 \mathrm{~s}\right)$ & Preheat $\left(200^{\circ} \mathrm{C}, 0 \mathrm{~s}\right)$ & Preheat $\left(200^{\circ} \mathrm{C}, 0 \mathrm{~s}\right)$ & \\
\hline $\operatorname{IRSL}\left(50^{\circ} \mathrm{C}, 200 \mathrm{~s}\right)$ & & & & $\mathrm{Tx}_{(50 / 290)}$ \\
\hline $\operatorname{IRSL}\left(290^{\circ} \mathrm{C}, 200 \mathrm{~s}\right)$ & $\operatorname{IRSL}\left(50^{\circ} \mathrm{C}, 100 \mathrm{~s}\right)$ & $\operatorname{OSL}\left(125^{\circ} \mathrm{C}, 40 \mathrm{~s}\right)$ & OSL $\left(125^{\circ} \mathrm{C}, 40 \mathrm{~s}\right)$ & $\mathrm{Tx}$ \\
\hline $\operatorname{IRSL}\left(325^{\circ} \mathrm{C}, 100 \mathrm{~s}\right)$ & IRSL $\left(280^{\circ} \mathrm{C}, 100 \mathrm{~s}\right)$ & OSL $\left(280^{\circ} \mathrm{C}, 40 \mathrm{~s}\right)$ & OSL $\left(280^{\circ} \mathrm{C}, 40 \mathrm{~s}\right)$ & \\
\hline
\end{tabular}


Table 3: Equivalent doses (Gy) and ages (ka) for the quartz OSL, IRSL and post-IR IRSL signals. For details see text.

\begin{tabular}{|c|c|c|c|c|c|c|c|c|}
\hline \multirow[t]{3}{*}{ Field ID } & \multirow[t]{2}{*}{ OSL } & \multirow[t]{2}{*}{ IRSL } & \multicolumn{2}{|c|}{ post-IR IRSL } & \multirow[t]{2}{*}{ OSL } & \multirow[t]{2}{*}{ IRSL } & \multicolumn{2}{|c|}{ post-IR IRSL } \\
\hline & & & IRSL $_{50 / 290}$ & $\mathrm{pIRIR}_{290}$ & & & IRSL $_{50 / 290}$ & pIRIR $_{290}$ \\
\hline & $\begin{array}{c}\mathrm{D}_{\mathrm{e}} \pm \text { s.e. } \\
{[\mathrm{Gy}]}\end{array}$ & $\begin{array}{c}\mathrm{D}_{\mathrm{e}} \pm \text { s.e. } \\
{[\mathrm{Gy}]}\end{array}$ & $\begin{array}{c}\mathrm{D}_{\mathrm{e}} \pm \text { s.e. } \\
{[\mathrm{Gy}]}\end{array}$ & $\begin{array}{c}\mathrm{D}_{\mathrm{e}} \pm \text { s.e. } \\
{[\mathrm{Gy}]}\end{array}$ & $\begin{array}{c}\text { age } \pm \text { s.e. } \\
{[\mathrm{ka}]}\end{array}$ & $\begin{array}{c}\text { age } \pm \text { s.e. } \\
{[\mathrm{ka}]}\end{array}$ & $\begin{array}{c}\text { age } \pm \text { s.e. } \\
{[\mathrm{ka}]}\end{array}$ & $\begin{array}{c}\text { age } \pm \text { s.e. } \\
{[\mathrm{ka}]}\end{array}$ \\
\hline PK1 & - & $67 \pm 4$ & $48 \pm 4$ & $77 \pm 5$ & - & $21.2 \pm 1.7$ & $15.3 \pm 1.4$ & $25 \pm 2$ \\
\hline PK2 & $65 \pm 2$ & $58.8 \pm 1.1$ & $68 \pm 7$ & $95 \pm 9$ & $27.7 \pm 1.4$ & $18.1 \pm 1.0$ & $21 \pm 2$ & $29 \pm 3$ \\
\hline PK3 & $63 \pm 2$ & $59.5 \pm 0.3$ & $51 \pm 2$ & $85 \pm 4$ & $26.9 \pm 1.5$ & $18.3 \pm 1.0$ & $15.6 \pm 1.1$ & $26 \pm 2$ \\
\hline PK4 & - & $54.9 \pm 1.7$ & $55 \pm 3$ & $86 \pm 4$ & - & $16.6 \pm 1.0$ & $16.6 \pm 1.3$ & $26 \pm 2$ \\
\hline PK5 & - & $73 \pm 5$ & $70 \pm 11$ & $108 \pm 20$ & - & $24 \pm 2$ & $22 \pm 4$ & $35 \pm 7$ \\
\hline PK6 & $75 \pm 4$ & $86 \pm 6$ & $70 \pm 4$ & $109 \pm 7$ & $30.1 \pm 1.9$ & $25 \pm 2$ & $20.1 \pm 1.6$ & $31 \pm 2$ \\
\hline PK7 & - & - & $80 \pm 8$ & $125 \pm 9$ & - & - & $24 \pm 3$ & $37 \pm 3$ \\
\hline PK8 & - & - & $60 \pm 9$ & $118 \pm 15$ & - & - & $18 \pm 3$ & $35 \pm 5$ \\
\hline PK9 & - & - & $70 \pm 8$ & $109 \pm 9$ & - & - & $21 \pm 3$ & $33 \pm 3$ \\
\hline PK10 & $73 \pm 4$ & - & $81 \pm 9$ & $130 \pm 9$ & $29.5 \pm 1.5$ & - & $24 \pm 3$ & $38 \pm 3$ \\
\hline PK11 & $190 \pm 21$ & - & $327 \pm 41$ & $689 \pm 90$ & $>80^{* *}$ & - & $95 \pm 13$ & $199 \pm 27$ \\
\hline PK12 & - & - & $312 \pm 30$ & $804 \pm 67$ & - & - & $87 \pm 9$ & $224 \pm 21$ \\
\hline PK13 & - & - & $311 \pm 36$ & $793 \pm 88$ & - & - & $90 \pm 11$ & $229 \pm 25$ \\
\hline PK14 & - & - & $356 \pm 18$ & $908 \pm 81$ & - & - & $102 \pm 7$ & $259 \pm 27$ \\
\hline PK17 & - & - & $213 \pm 38$ & $853 \pm 102$ & - & - & $72 \pm 13$ & $287 \pm 36$ \\
\hline PK20 & - & - & $656 \pm 41$ & $>1000^{*}$ & - & - & $190 \pm 15$ & $>290$ \\
\hline PK22 & - & - & $600 \pm 160$ & $>1000^{*}$ & - & - & $160 \pm 50$ & $>260$ \\
\hline PK23 & - & - & $518 \pm 91$ & $>1000^{*}$ & - & - & $140 \pm 30$ & $>270$ \\
\hline
\end{tabular}

* Signal close to saturation

** Minimum age due to saturation of the quartz OSL signal $\left(D_{e}>2 * D_{0}\right.$; Wintle and Murray, 2006). 


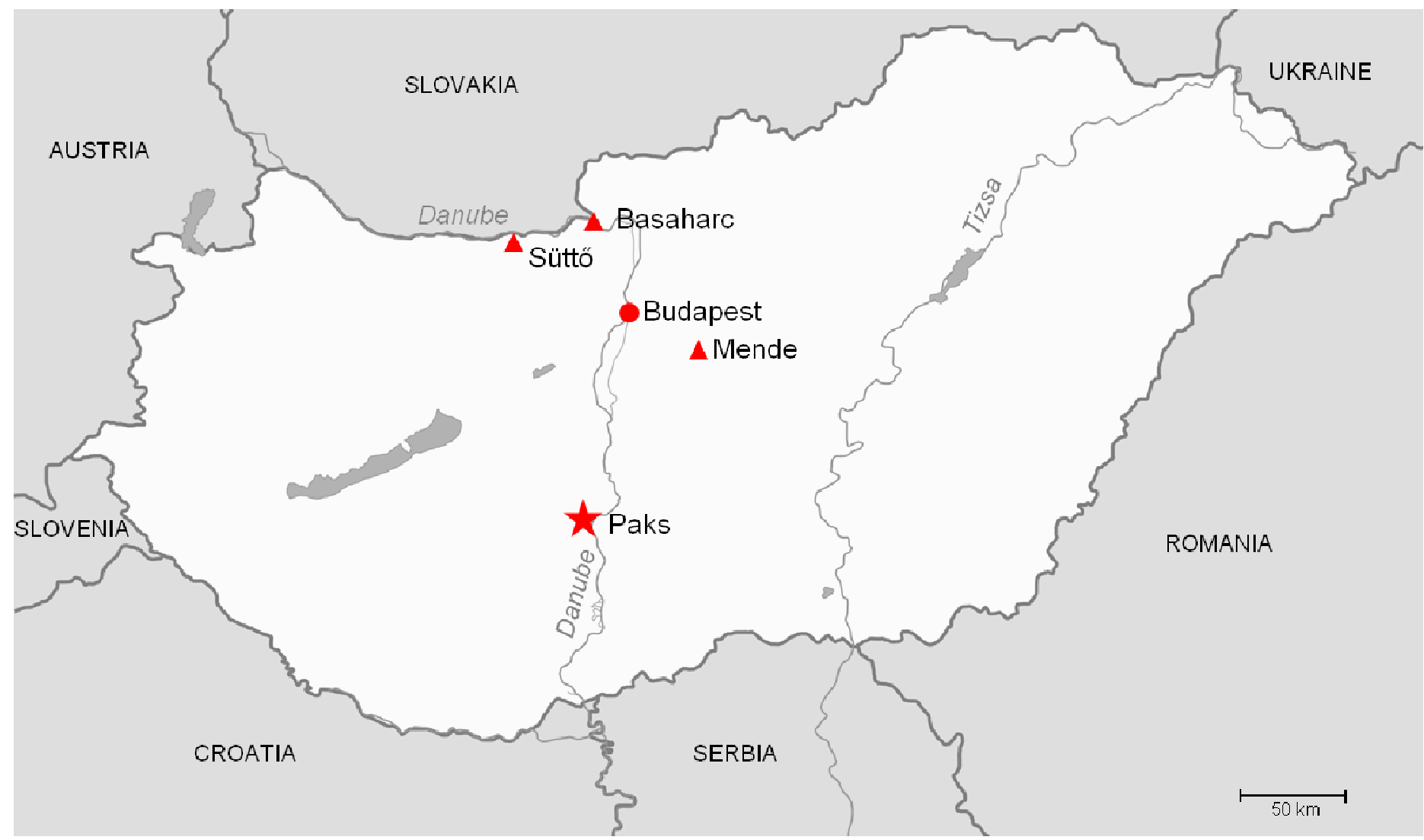

Thiel et al., Fig. 1 

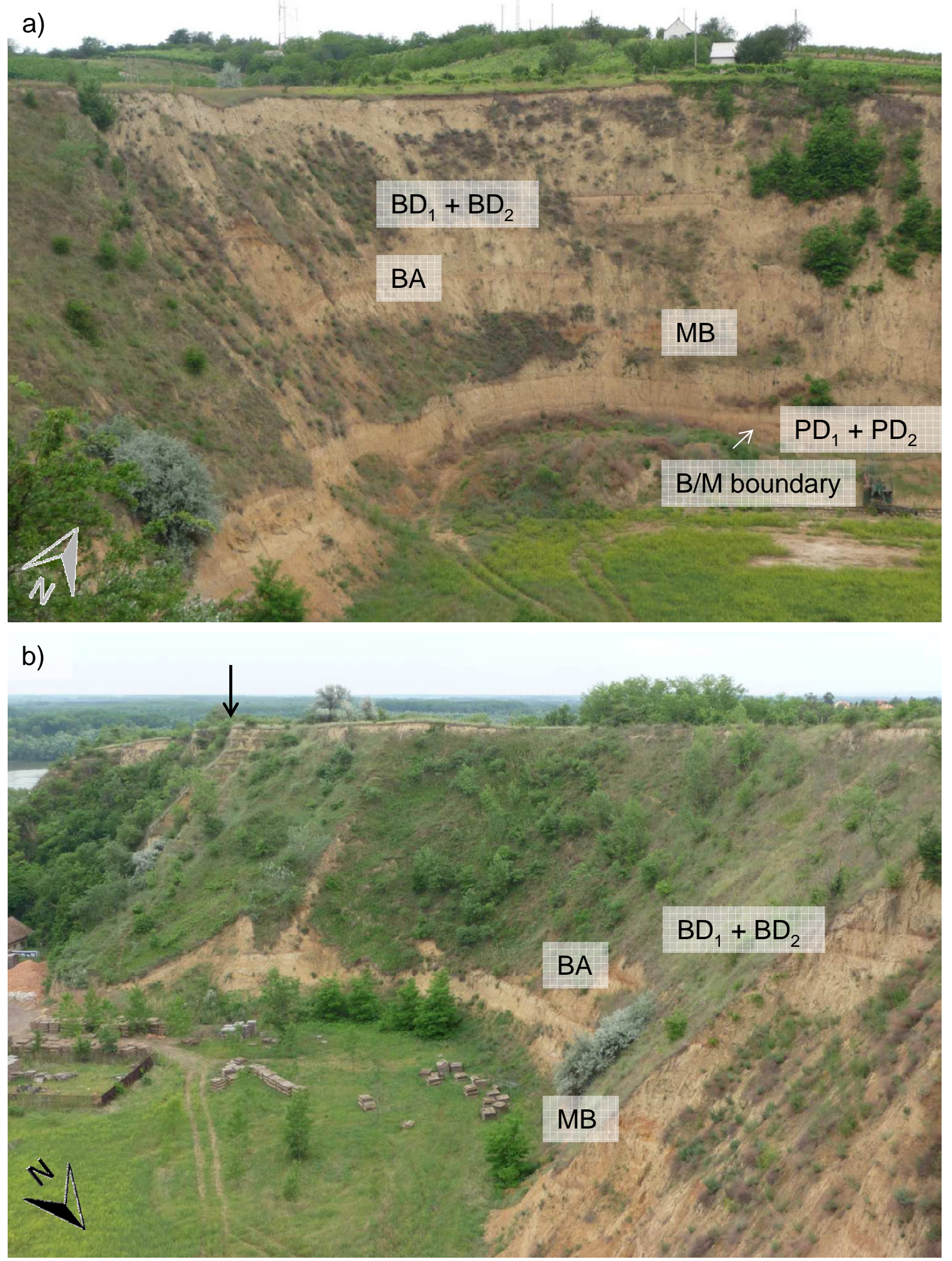

Thiel et al., Fig. 2 


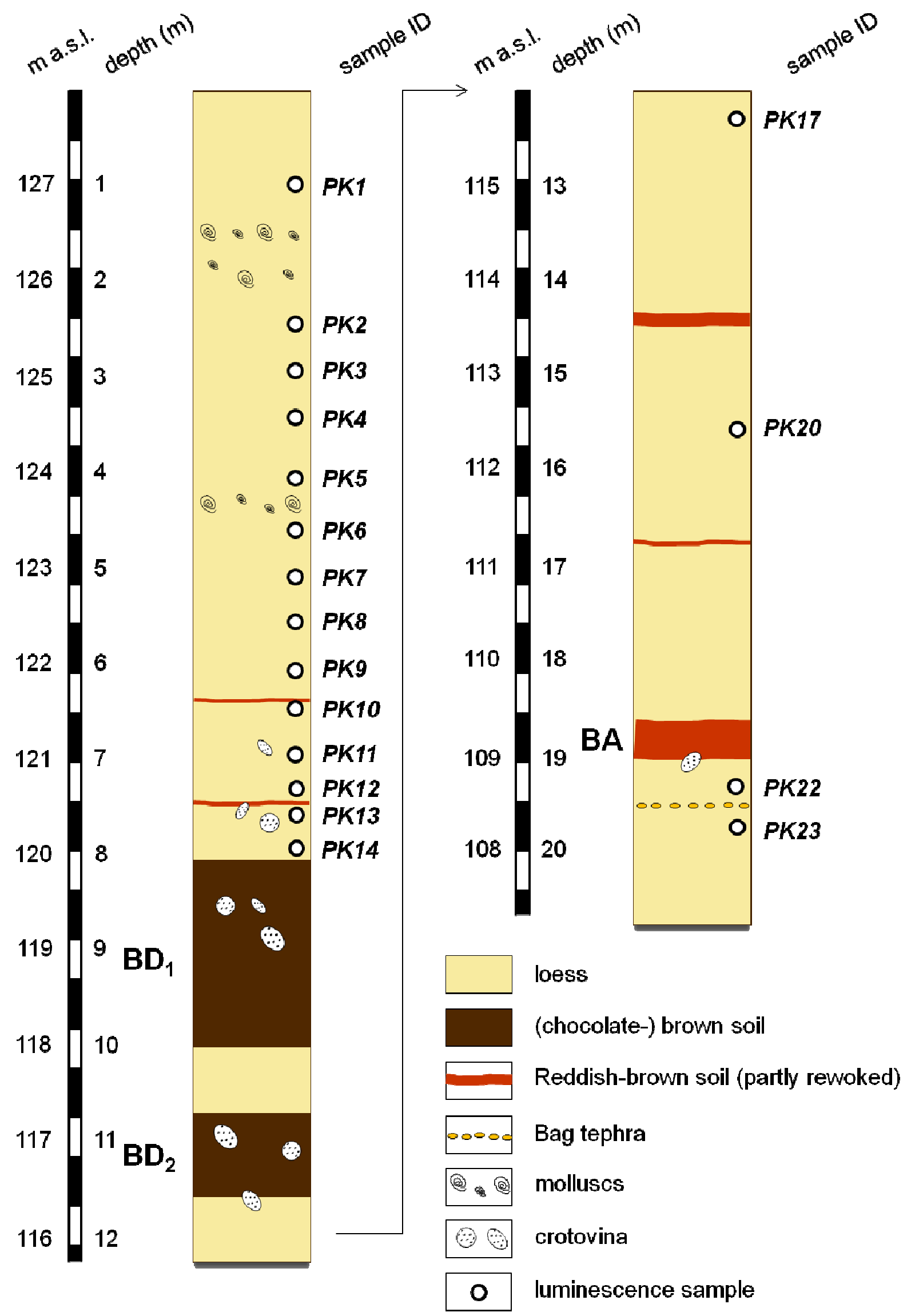

Thiel et al., Fig. 3 

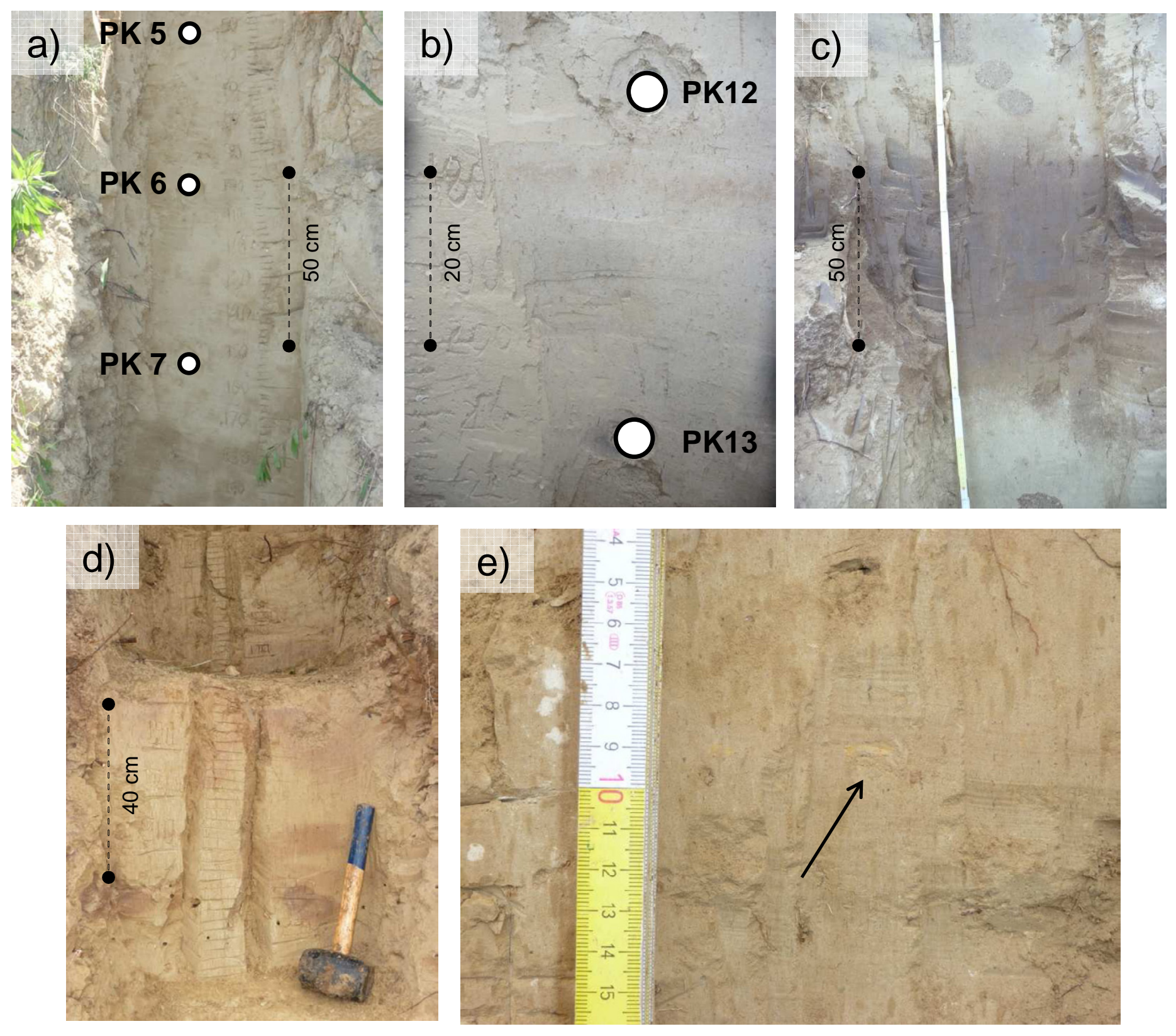

Thiel et al., Fig. 4 

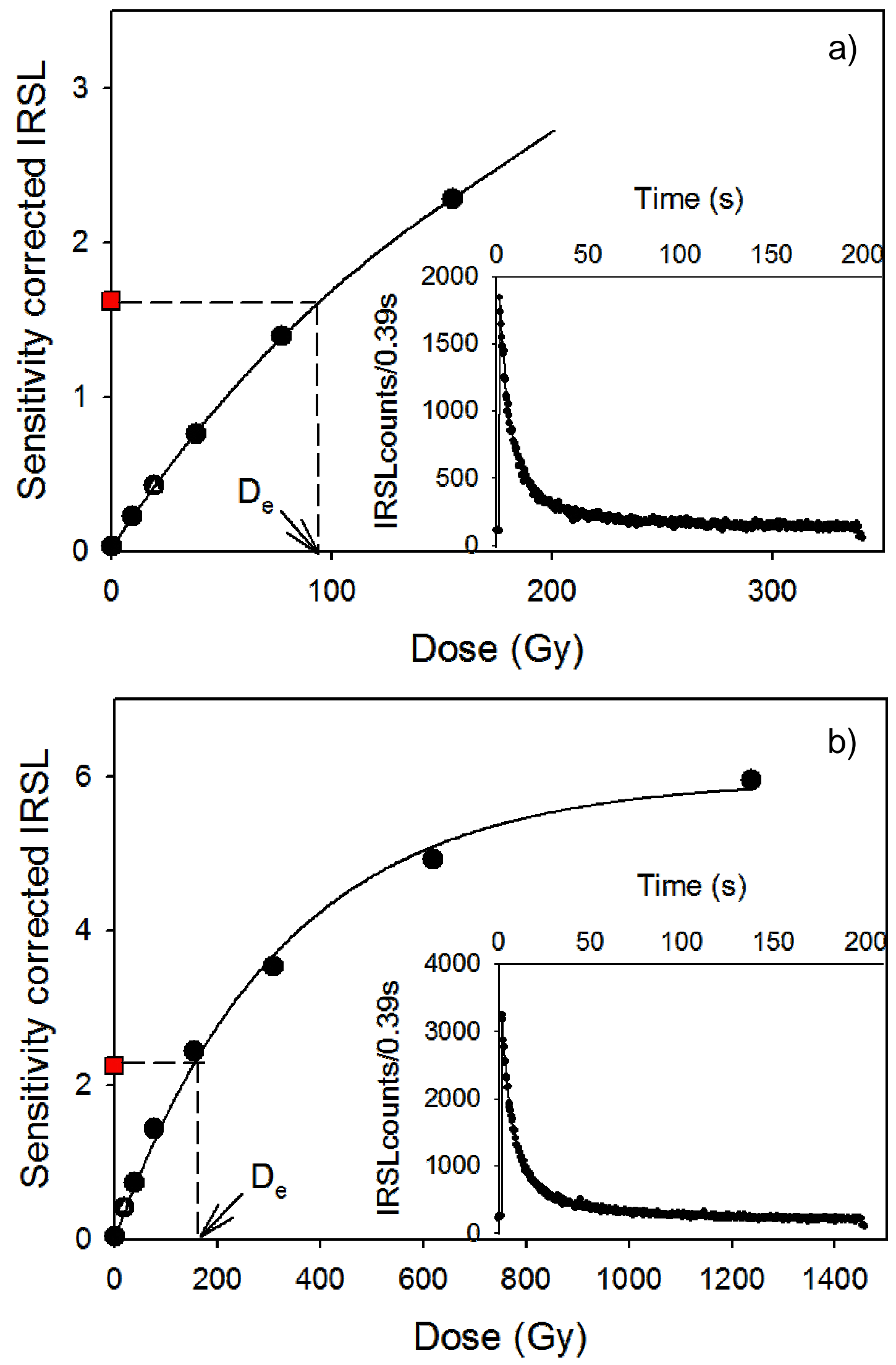

Thiel et al., Fig. 5 


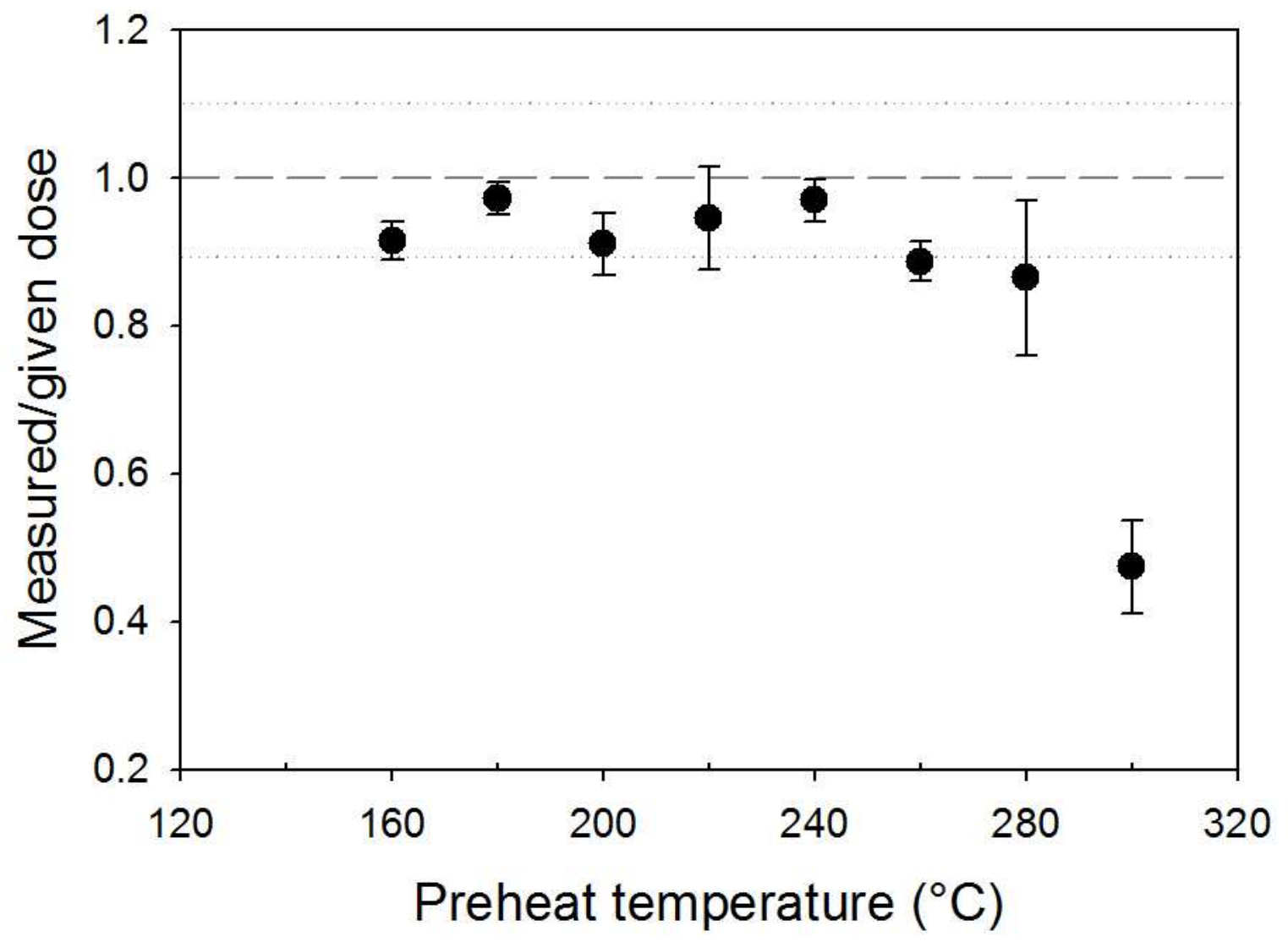

Thiel et al., Fig. 6 


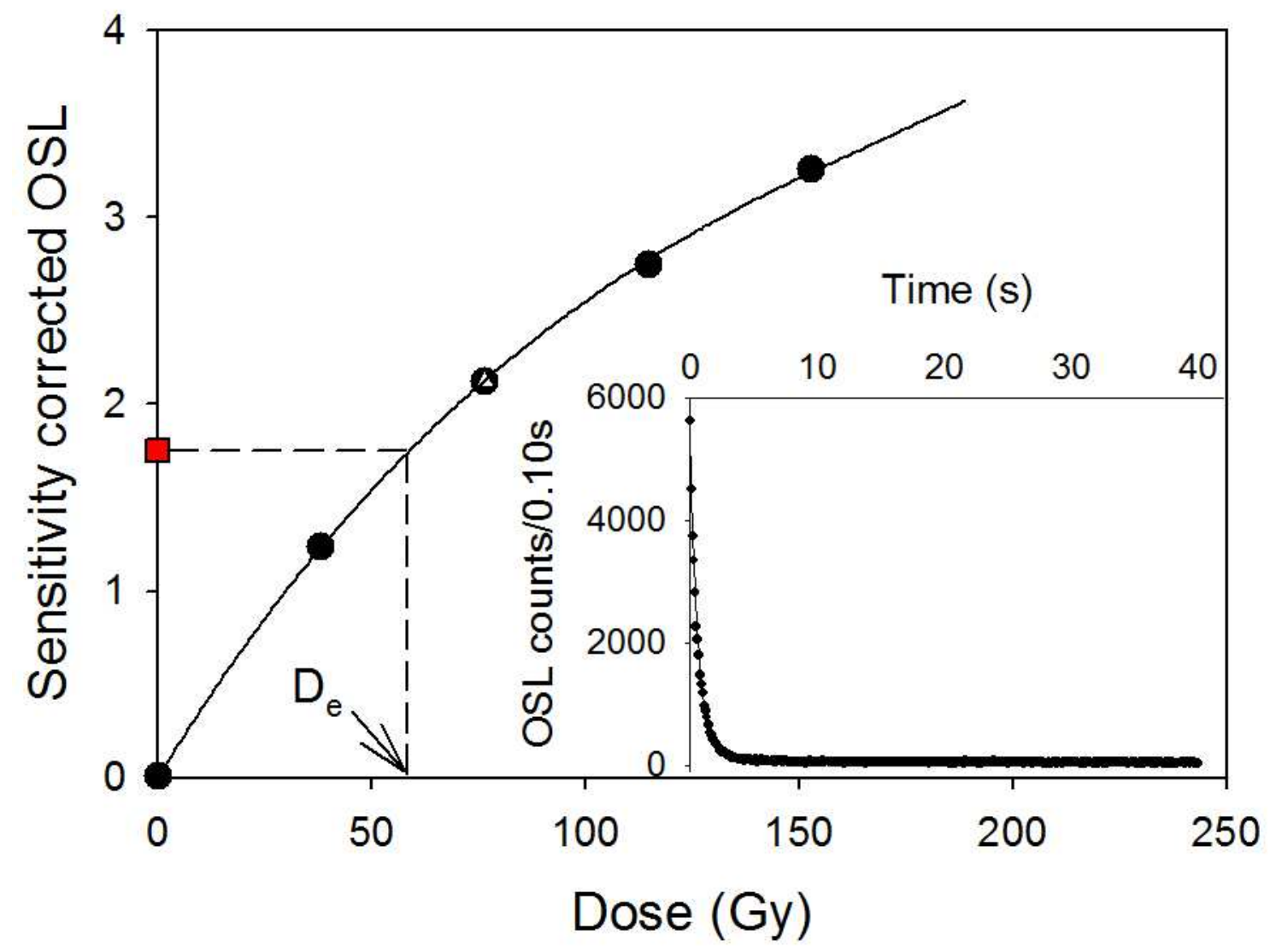

Thiel et al., Fig. 7 
Age (ka)

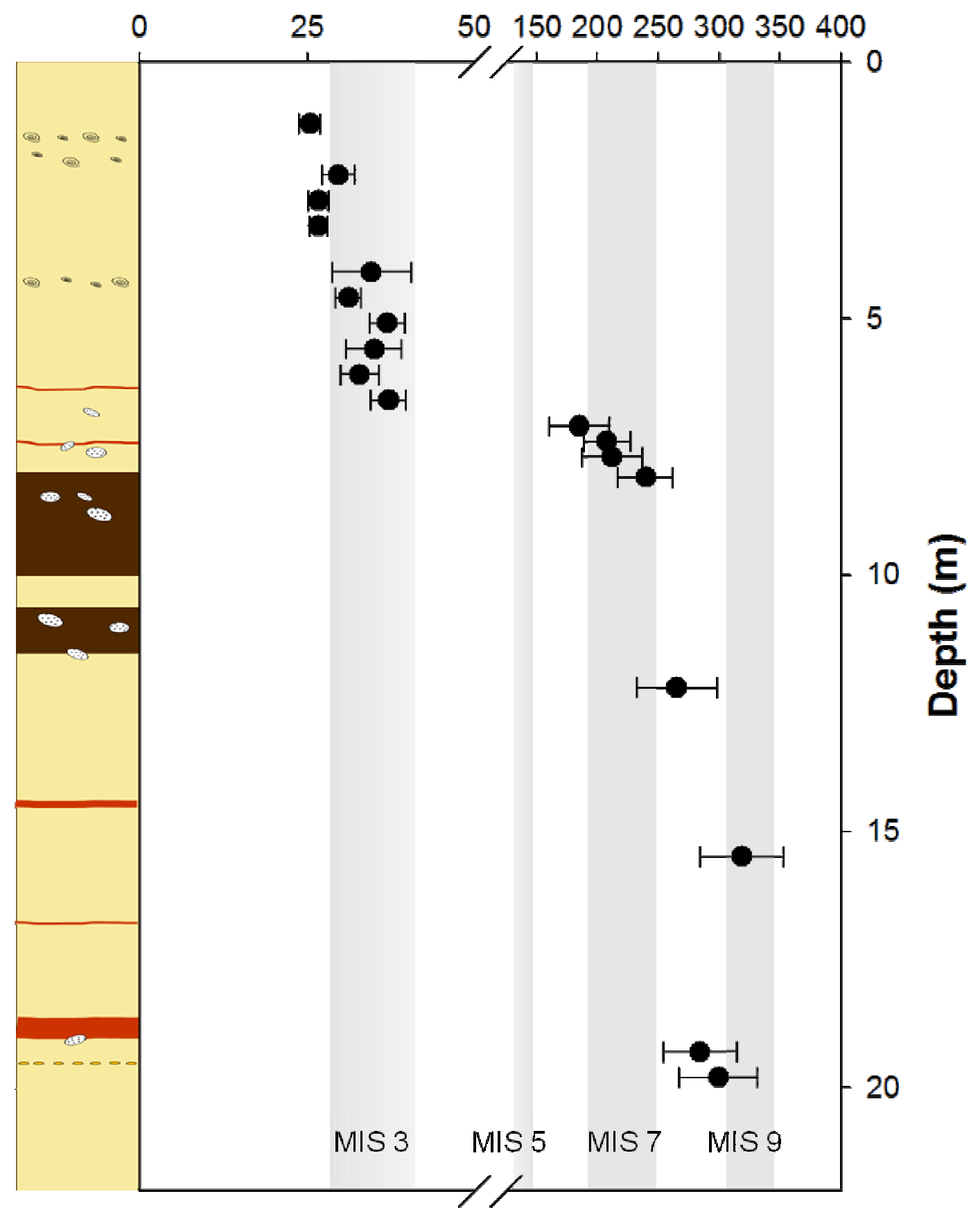

Thiel et al., Fig. 8 


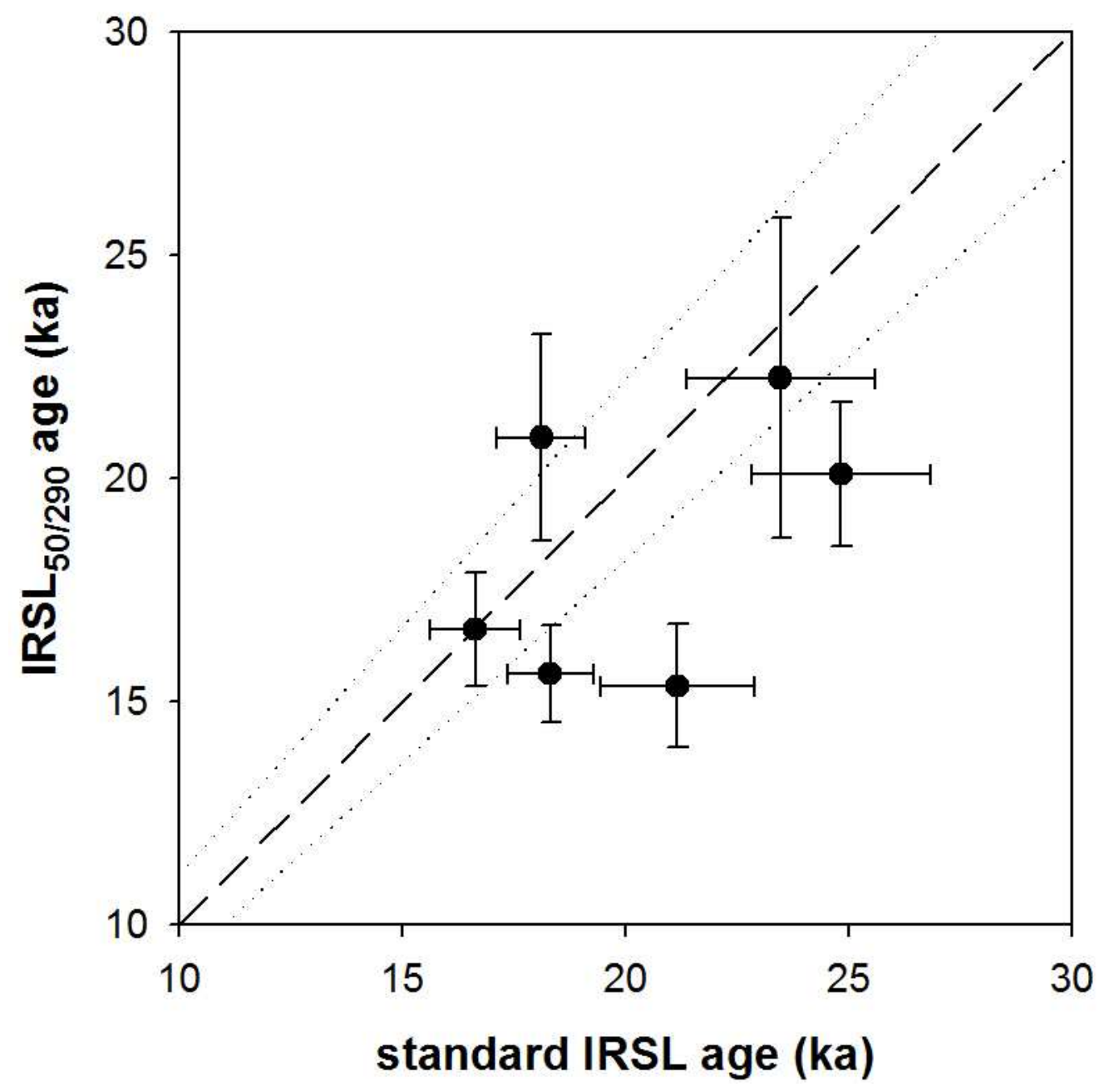

Thiel et al., Fig. 9 


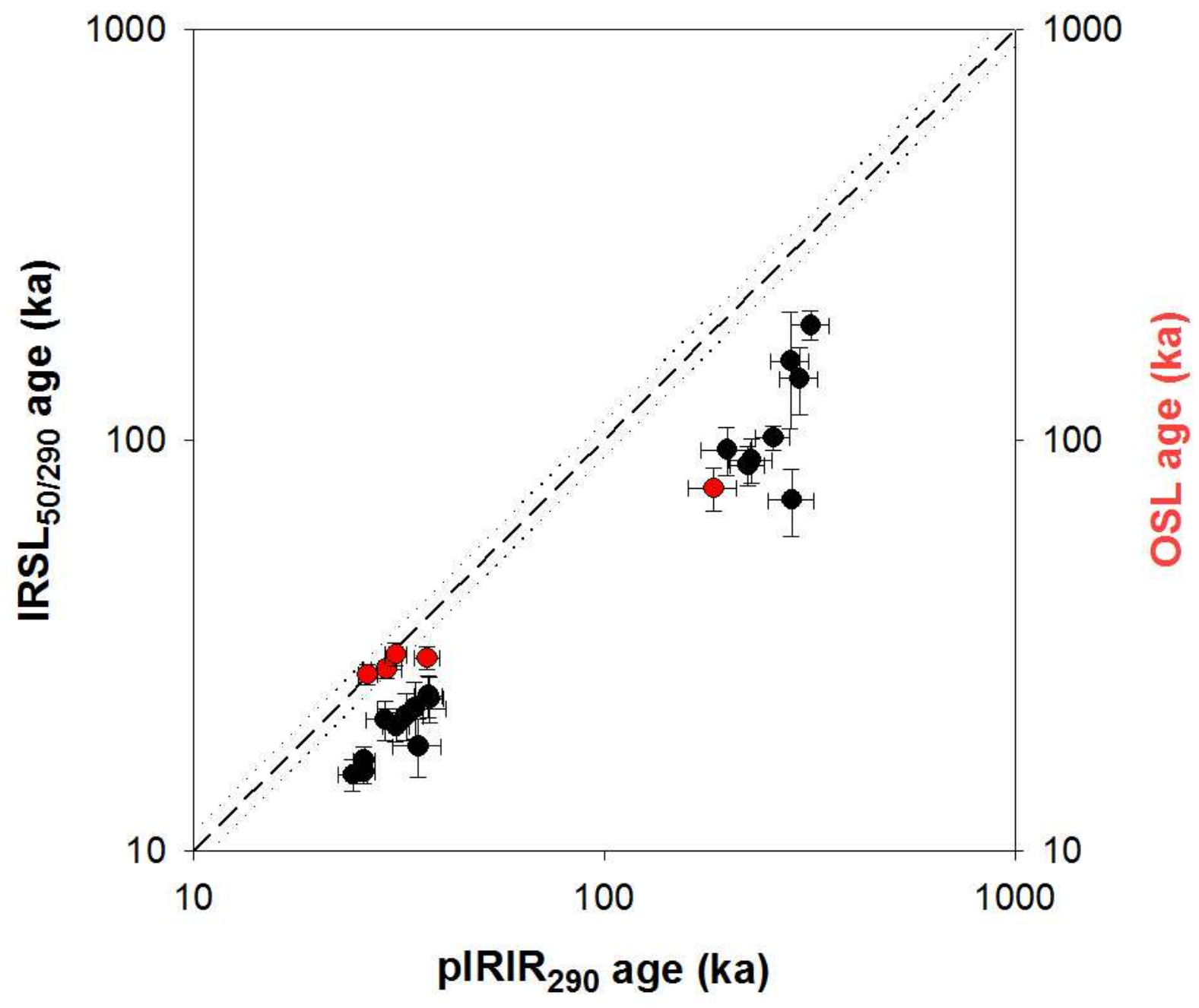

Thiel et al., Fig. 10 